Prepared in cooperation with the Federal Emergency Management Agency

\title{
Climate Simulation and Flood Risk Analysis for 2008-40 for Devils Lake, North Dakota
}

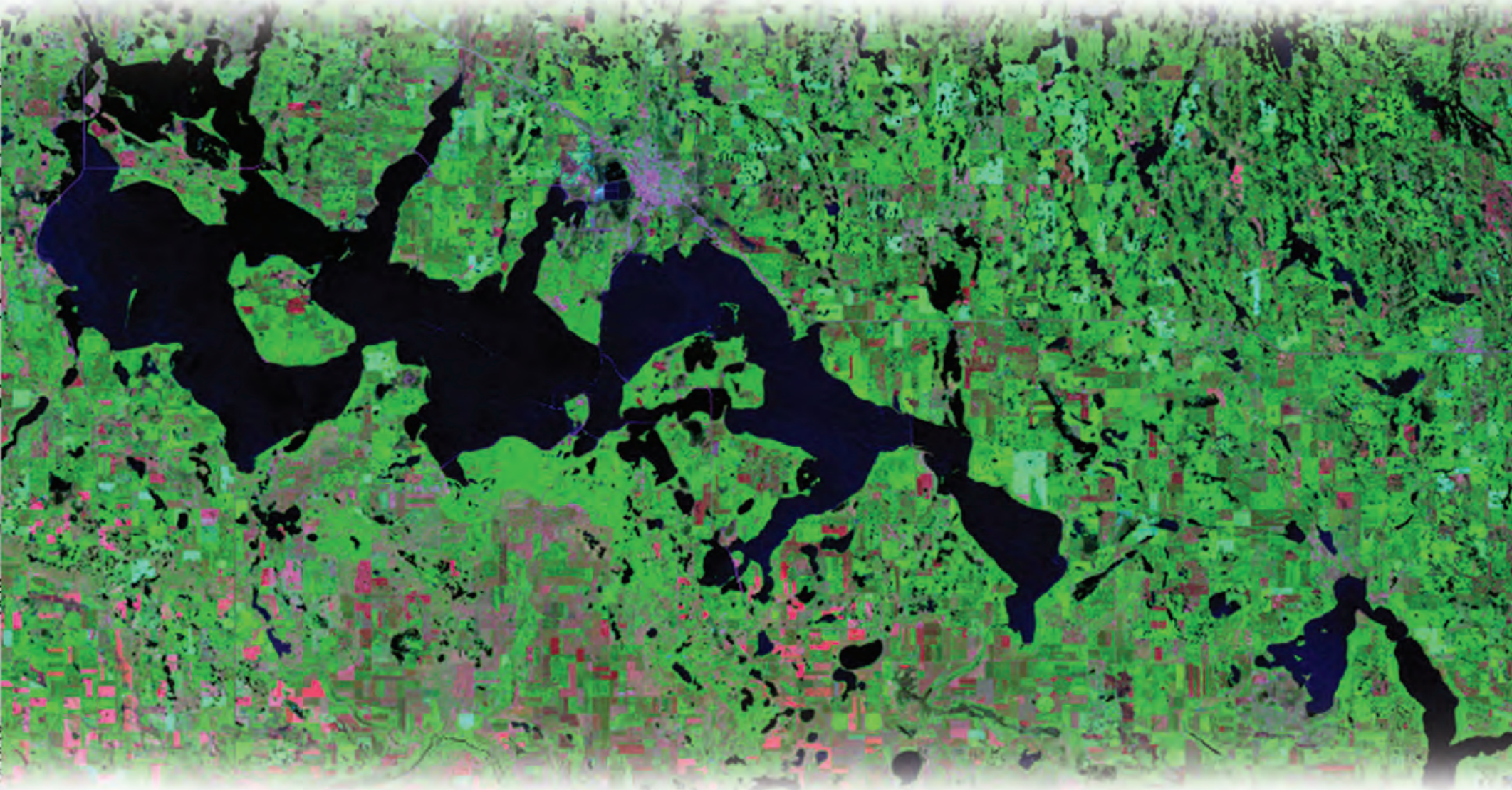

Scientific Investigations Report 2008-5011 
Cover photograph: Landsat image of Devils Lake, North Dakota, 1997. Data available from U.S. Geological Survey Center for Earth Resources Observation and Science (EROS), Sioux Falls, South Dakota. 


\section{Climate Simulation and Flood Risk Analysis for 2008-40 for Devils Lake, North Dakota}

By Aldo V. Vecchia

Prepared in cooperation with the Federal Emergency Management Agency

Scientific Investigations Report 2008-5011 


\section{U.S. Department of the Interior DIRK KEMPTHORNE, Secretary}

\section{U.S. Geological Survey \\ Mark D. Myers, Director}

\section{U.S. Geological Survey, Reston, Virginia: 2008}

For product and ordering information:

World Wide Web: http://www.usgs.gov/pubprod

Telephone: 1-888-ASK-USGS

For more information on the USGS — the Federal source for science about the Earth, its natural and living resources, natural hazards, and the environment:

World Wide Web: http://www.usgs.gov

Telephone: 1-888-ASK-USGS

Any use of trade, product, or firm names is for descriptive purposes only and does not imply endorsement by the U.S. Government.

Although this report is in the public domain, permission must be secured from the individual copyright owners to reproduce any copyrighted materials contained within this report.

Suggested citation:

Vecchia, A.V., 2008, Climate simulation and flood risk analysis for 2008-40 for Devils Lake, North Dakota: U.S. Geological Survey Scientific Investigations Report 2008-5011, 28 p. 


\section{Contents}

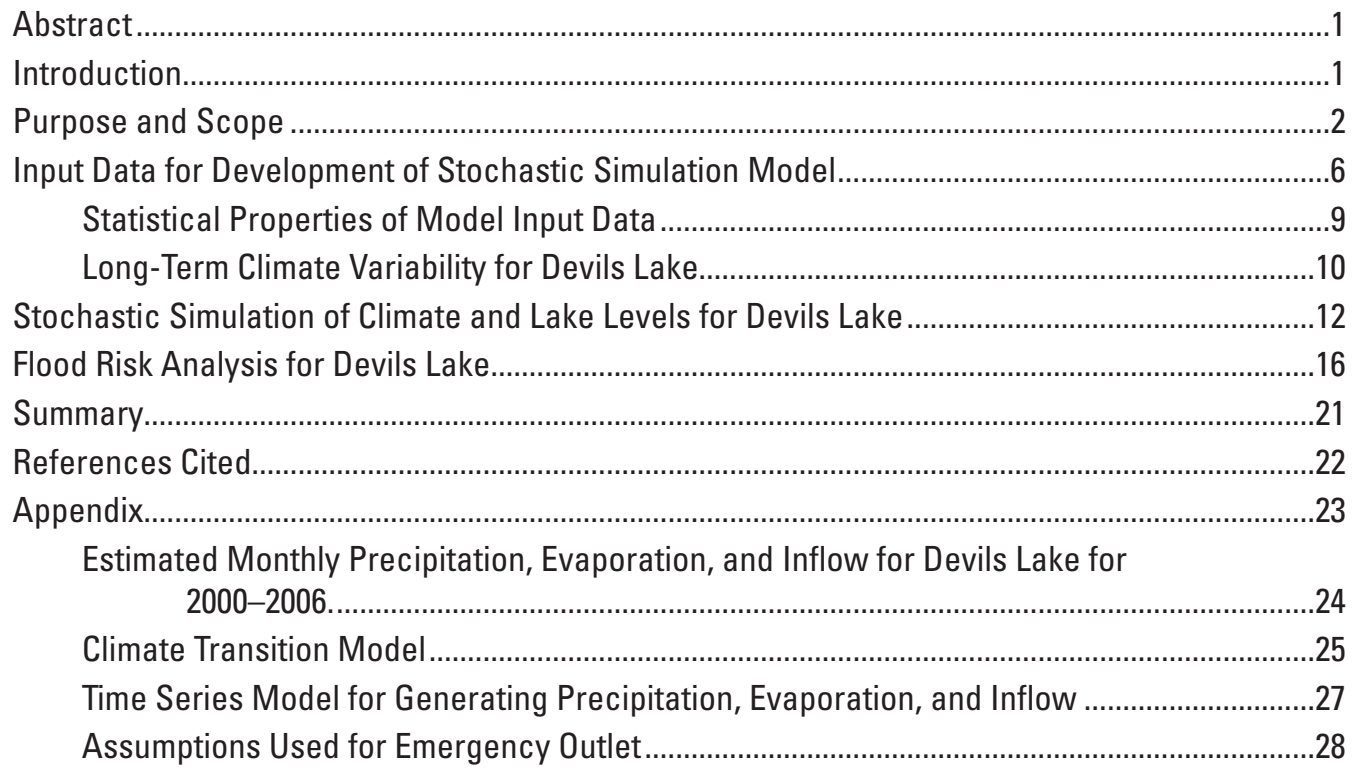

\section{Figures}

1-2. Maps showing:

1. Location of the Devils Lake Basin in North Dakota ...................................................

2. Locations of U.S. Geological Survey gaging stations used for Devils Lake flood risk analysis.

3-13. Graphs showing:

3. Recorded elevations of Devils Lake for 1868-2007 ...................................................5

4. Measured monthly volume changes for Devils Lake for 2000-2006 and fitted volume changes from the water mass-balance model..............................8

5. Measured monthly volume changes for Stump Lake for 2000-2006 and fitted volume changes from the water mass-balance model..............................8

6. Estimated annual precipitation for Devils Lake for $1950-2006$...................................10

7. Estimated annual evaporation for Devils Lake for 1950-2006 ...................................11

8. Estimated annual inflow for Devils Lake for 1950-2006...........................................11

9. Five-year moving average of annual precipitation for 1,500 years generated from the climate transition model with 30 -year average duration of the wet periods and 120-year average duration of the dry periods

10. Historical and generated annual maximum lake levels for Devils Lake for 1950-2040, assuming the current wet period lasts until 2010

11. Historical and generated annual maximum lake levels for Devils Lake for 1950-2040, assuming the current wet period lasts until 2038

12. Cumulative exceedance elevations for Devils Lake for 2008-40, computed by using 10,000 traces from the Devils Lake stochastic simulation model. 
13. Flood elevations for Devils Lake for 2008-40 for annualized risks of $0.5,1$, and 2 percent, computed by using 10,000 traces from the Devils Lake stochastic simulation model.

A1. Five-year moving average of annual precipitation for 1,500 years generated from the climate transition model with 24-year average duration of the wet periods and 78-year average duration of the dry periods.

\section{Tables}

1. Selected U.S. Geological Survey gaging stations in the Devils Lake Basin.. .7

2. Monthly multipliers applied to precipitation and potential evapotranspiration data from the Devils Lake National Weather Service station to obtain estimated precipitation and evaporation for the Devils Lake water-balance model..

3. Cumulative flood elevations for Devils Lake for 2008-40 for cumulative exceedance probabilities of $1,5,10,20$, and 50 percent

4. Flood elevations for Devils Lake for 2008-40 for annualized risks of $0.5,1$, and 2 percent

A1. Recurrence intervals and average durations of wet and dry periods.

A2. Statistical properties of generated annual precipitation, evaporation, and inflow data for Devils Lake for representative climate periods 1950-79, 1980-99, and 1980-2006.

A3. Assumptions regarding North Dakota Devils Lake Emergency Outlet. .28

\section{Conversion Factors}

Inch/Pound to SI

\begin{tabular}{lcl}
\hline Multiply & By & To obtain \\
\hline foot $(\mathrm{ft})$ & Length & \\
mile $(\mathrm{mi})$ & 0.3048 & meter $(\mathrm{m})$ \\
\hline & 1.609 & kilometer $(\mathrm{km})$ \\
\hline acre & Area & \\
square mile $\left(\mathrm{mi}^{2}\right)$ & 4,047 & square meter $\left(\mathrm{m}^{2}\right)$ \\
& 2.590 & square kilometer $\left(\mathrm{km}^{2}\right)$ \\
\hline cubic foot $\left(\mathrm{ft}^{3}\right)$ & Volume & \\
acre-foot $(\mathrm{acre}-\mathrm{ft})$ & 0.02832 & cubic meter $\left(\mathrm{m}^{3}\right)$ \\
\hline
\end{tabular}

All lake levels and elevations in this report are referenced to the National Geodetic Vertical Datum (NGVD) of 1929. 


\title{
Climate Simulation and Flood Risk Analysis for 2008-40 for Devils Lake, North Dakota
}

\author{
By A.V. Vecchia
}

\section{Abstract}

Devils Lake and Stump Lake in northeastern North Dakota receive surface runoff from a 3,810-square-mile drainage basin, and evaporation provides the only major water loss unless the lakes are above their natural spill elevation to the Sheyenne River. In September 2007, flow from Devils Lake to Stump Lake had filled Stump Lake and the two lakes consisted of essentially one water body with an elevation of 1,447.1 feet, about 3 feet below the existing base flood elevation (1,450 feet) and about 12 feet below the natural outlet elevation to the Sheyenne River (1,459 feet).

Devils Lake could continue to rise, causing extensive additional flood damages in the basin and, in the event of an uncontrolled natural spill, downstream in the Red River of the North Basin. This report describes the results of a study conducted by the U.S. Geological Survey, in cooperation with the Federal Emergency Management Agency, to evaluate future flood risk for Devils Lake and provide information for developing updated flood-insurance rate maps and planning flood-mitigation activities such as raising levees or roads.

In about 1980, a large, abrupt, and highly significant increase in precipitation occurred in the Devils Lake Basin and elsewhere in the Northern Great Plains, and wetter-thannormal conditions have persisted through the present (2007). Although future precipitation is impossible to predict, paleoclimatic evidence and recent research on climate dynamics indicate the current wet conditions are not likely to end anytime soon. For example, there is about a 72-percent chance wet conditions will last at least 10 more years and about a 37 -percent chance wet conditions will last at least 30 more years.

A stochastic simulation model for Devils Lake and Stump Lake developed in a previous study was updated and used to generate 10,000 potential future realizations, or traces, of precipitation, evaporation, inflow, and lake levels given existing conditions on September 30, 2007, and randomly generated future duration of the current wet period. On the basis of the simulations, and assuming ice-free conditions and calm wind, the Devils Lake flood elevation for an annualized flood risk of 1 percent (analogous to a "100-year" riverine flood) was estimated to be 1,454.6 feet for a 10-year time horizon (2008-17).
Therefore, without adjusting for wind or ice, a residence near Devils Lake at elevation 1,454.6 feet has the same chance of being flooded sometime during the next 10 years as a residence at the edge of the 100-year flood plain along a river. Adjusting for the effects of wind or ice, which will increase the flood elevations for many locations near the lakes, was not within the scope of this study.

\section{Introduction}

The Devils Lake Basin is a 3,810-square-mile subbasin of the Red River of the North (Red River) Basin (fig. 1). About 3,320 square miles of the basin is tributary to Devils Lake and the remainder is tributary to Stump Lake. At an elevation of 1,446.5 feet, Devils Lake begins to spill into Stump Lake, and at an elevation of about 1,459 feet, the combined Devils Lake and Stump Lake system begins to spill from Stump Lake, through Tolna Coulee, to the Sheyenne River (fig. 2).

Lake levels of Devils Lake were recorded sporadically from 1867 to 1890, and in 1901 the U.S. Geological Survey (USGS) established a gaging station on Devils Lake. From 1867 through 2007, the lake level fluctuated between a minimum of 1,400.9 feet (nearly dry) in 1940 and a maximum of 1,449.2 feet in May 2006 (fig. 3). On October 1, 1992, the combined volume of Devils Lake and Stump Lake was about 590,000 acre-feet and the combined surface area was about 49,000 acres. Water began spilling from Devils Lake to Stump Lake in May 1999, and by September 2007 Devils Lake and Stump Lake became essentially one continuous water body with an elevation of 1,447.1 feet, a combined volume of about 2.9 million acre-feet, and a combined surface area of about 140,000 acres. Therefore, from 1992 to 2007 the combined volume increased by about 2.3 million acre-feet and the combined area increased by about 91,000 acres.

The rising water of Devils Lake and Stump Lake has destroyed hundreds of homes and businesses and inundated thousands of acres of productive farmland. Since 1993, the State of North Dakota and the U.S. Government has spent more than $\$ 450$ million in flood-mitigation efforts, including more than $\$ 59$ million for raising levees to protect the city of Devils Lake and surrounding areas and \$178 million for 
raising or improving roads and highways (North Dakota State Water Commission, written commun., 2002; North Dakota Department of Transportation, written commun., 2005).

If Devils Lake and Stump Lake continue to rise, an uncontrolled natural spill to the Sheyenne River could occur. According to Murphy and others (1997), Stump Lake (and hence Devils Lake) spilled to the Sheyenne River at least twice in the past 4,000 years. If such a spill occurred in future years and the Tolna Coulee outlet was not modified to control erosion, the outlet could erode quickly, causing extensive downstream flooding, channel erosion, and water quality degradation (U.S. Army Corps of Engineers, 2003).

In 1993, Devils Lake rose above its highest level for more than 100 years, prompting a study by the North Dakota State Water Commission (NDSWC), in cooperation with the USGS, to evaluate the lake level used for establishing flood insurance rate maps (FIRMs) for Devils Lake and surrounding areas. In 1996, the results of that study were published (Wiche and Vecchia, 1996). On the basis of the best information available at that time, the long-term 1-percent exceedance elevation (the lake level that was exceeded an average of 1 percent of the time since the end of glaciation, about 10,000 years ago) was estimated to be approximately 1,445 feet. That elevation was about 8 feet higher than the lake level in 1996, and about 10 feet higher than the previously established flood elevation (1,435 feet). However, Devils Lake continued to rise and by 1999 the lake level exceeded 1,445 feet, prompting the Federal Emergency Management Agency (FEMA) to raise the base flood elevation for most of the areas surrounding Devils Lake to the current elevation of 1,450 feet (Federal Emergency Management Agency, 2000). In 2000, Congress directed the U.S. Army Corps of Engineers (COE) to complete preconstruction engineering and design and an associated Environmental Impact Statement for an emergency outlet from Devils Lake.

As part of the emergency-outlet planning process, the USGS developed a Devils Lake stochastic simulation model for the COE (Vecchia, 2002). Updated information through 1999 and more detailed hydrologic and climatologic analyses than what were available in earlier reports indicated that long-term hydroclimatic variability in the Devils Lake Basin and elsewhere in the Northern Great Plains was much greater than previously thought. The long-term geologic record of Devils Lake levels (Murphy and others, 1997) was found to be consistent with a two-state climate model in which climatic conditions randomly shifted between "normal" periods, similar to conditions that occurred during 1950-79, and "wet" periods, similar to conditions that occurred during 1980-99. The average duration of the normal periods was estimated to be 120 years and the average duration of the wet periods was estimated to be 20 years. There was estimated to be only a small chance (about 1 in 50) of Devils Lake rising above the spill elevation to Stump Lake during extended normal periods (such as occurred from before European settlement in the mid1800 's through most of the 1900's). Conversely, there was estimated to be more than a 1 in 2 chance of Devils Lake spilling to Stump Lake and more than a 1 in 20 chance of Devils Lake spilling to the Sheyenne River sometime during a 20-year wet climatic period. Because strong evidence suggests that a wet period began in about 1980 and continues through the present (2007), it seems imperative that flood risk for Devils Lake needs to be re-examined. Given that the region is in the midst of a prolonged wet period, Stump Lake is full, and the current lake level $(1,447.1$ feet $)$ is less than 3 feet below the existing base flood elevation, a study was initiated in cooperation with FEMA to provide the most up-to-date and scientifically defensible estimates of future flood risk for Devils Lake and Stump Lake.

\section{Purpose and Scope}

The purpose of this report is to describe climate simulation and flood risk analysis for 2008-2040 for Devils Lake, North Dakota. In the report, previously published estimates of monthly precipitation, evaporation, and inflow data for Devils Lake for 1950-99 are extended to include data for 2000-2006, the data are used to recalibrate the Devils Lake stochastic simulation model, and new estimates of future flood risk for Devils Lake and Stump Lake are provided. Recent research on long-term regional climate variability will be used to provide a sound scientific basis for the climatic assumptions used to generate potential future lake levels and estimate future flood risk. The report can be used by FEMA, COE, and other agencies for developing updated flood-insurance rate maps and planning flood-mitigation activities such as levee raises, road raises, or other infrastructure improvements.

The flood elevations described in this report are for the USGS Devils Lake gage on Creel Bay (site 10, fig. 2). Flood elevations for some areas, such as areas surrounding Pelican Lake, Lakes Alice and Irvine, Dry Lake, or other upstream lakes that are currently connected to Devils Lake, may need to be increased to account for flow restrictions. Such adjustments are not part of the scope of this report. Also, the flood elevations described in this report are for calm conditions and open water, and thus do not include adjustments for the effects of wind or ice. Finally, the effects of recent (2007) or pending construction to improve roads acting as water barriers were not incorporated into this report. The reduction in available storage resulting from that construction is estimated to result in an increase of 0.0 to 0.12 foot in future water-surface elevations (Rick Hauck, U.S. Army Corps of Engineers, written commun., 2007). 


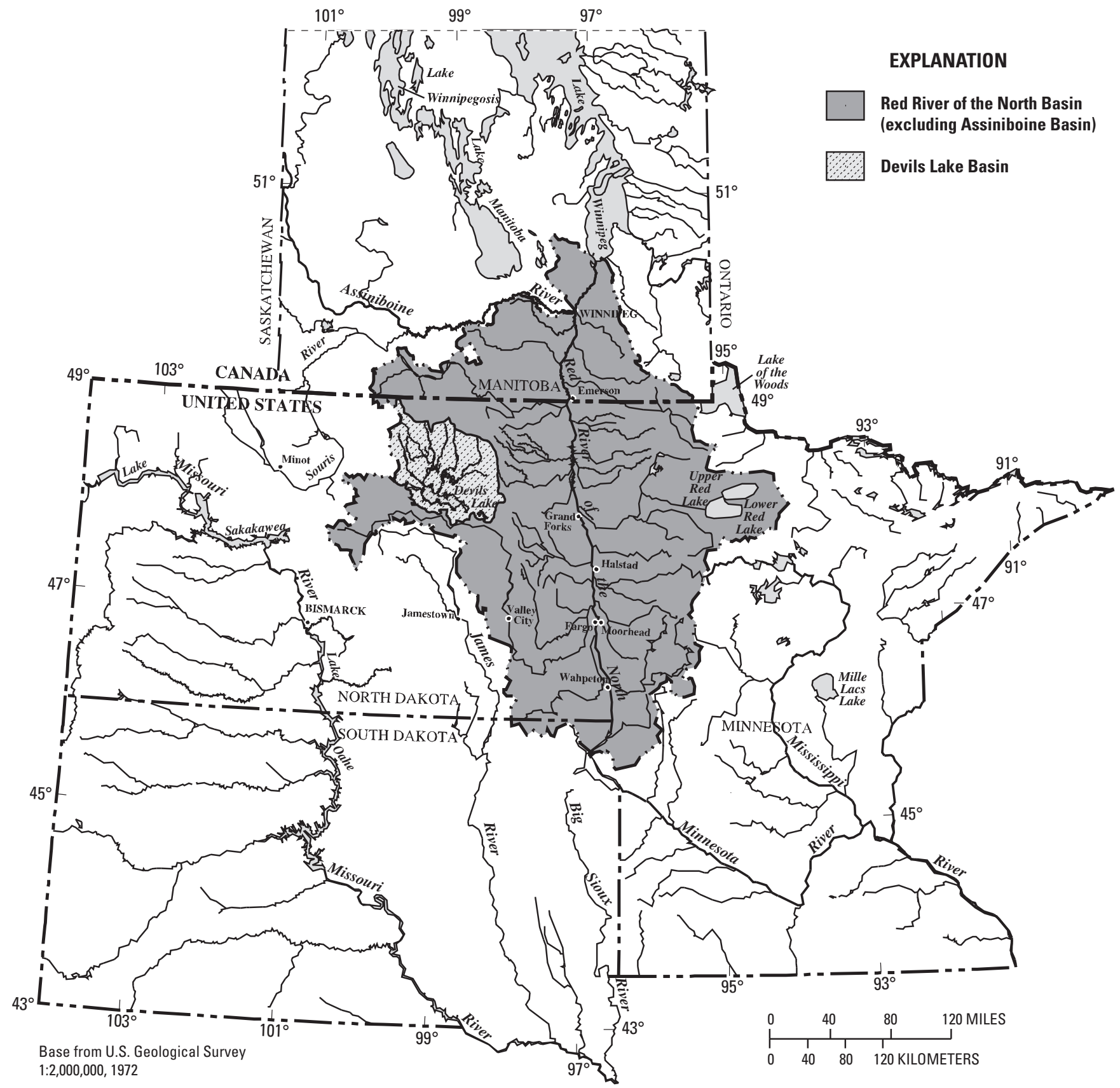

Figure 1. Location of the Devils Lake Basin in North Dakota. 


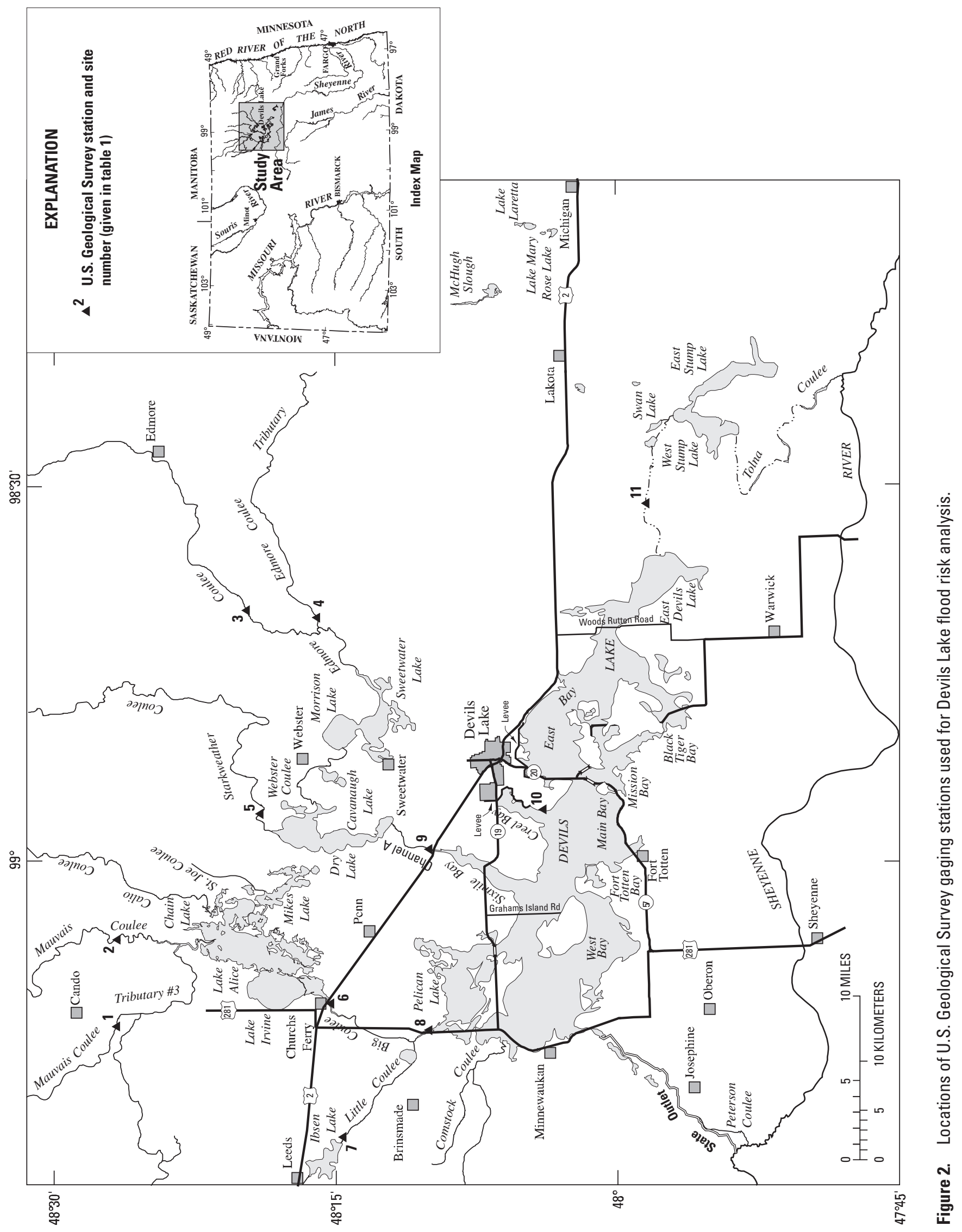




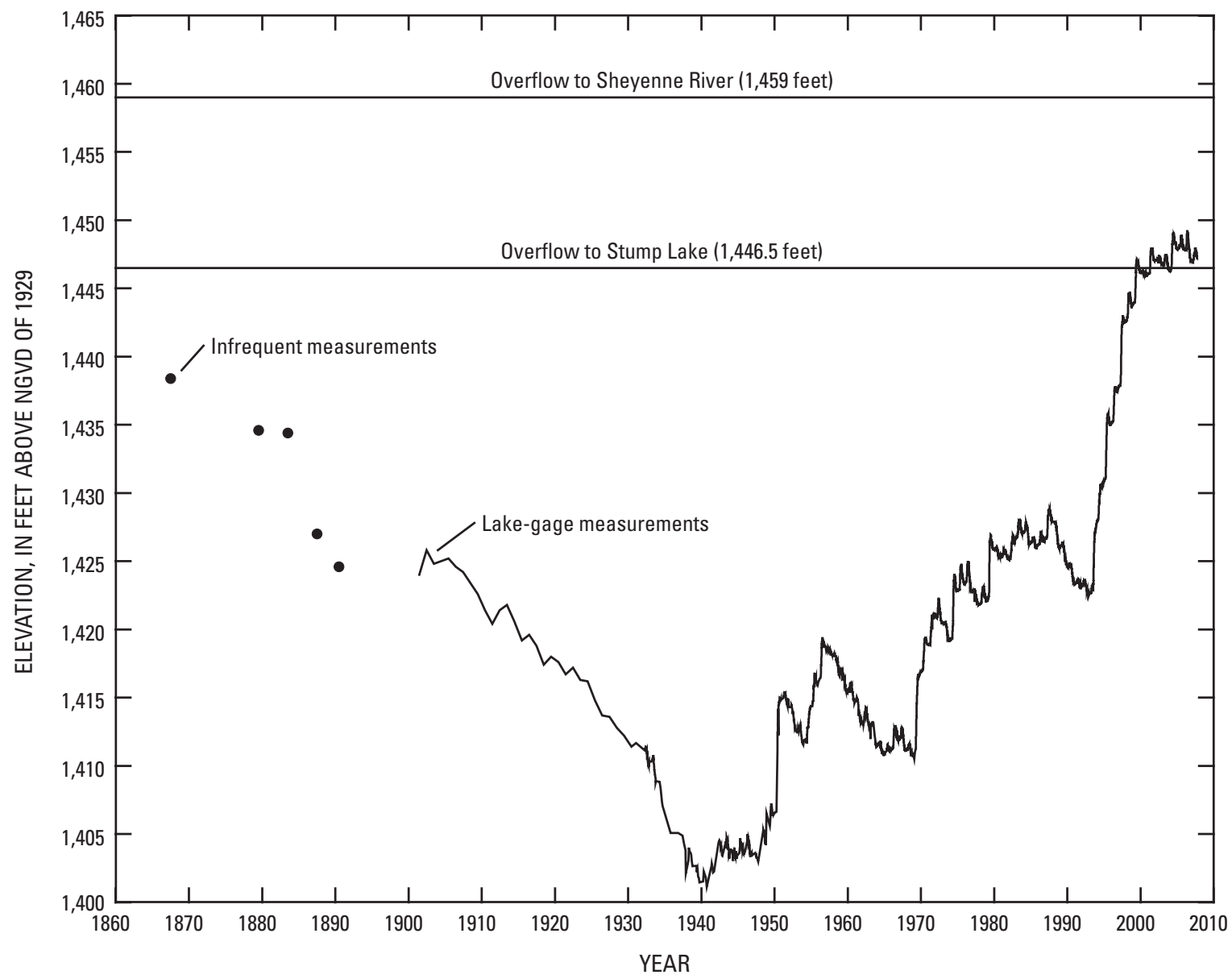

Figure 3. Recorded elevations of Devils Lake for 1868-2007. 


\section{Input Data for Development of Stochastic Simulation Model}

Developing new modeling techniques and gathering extensive data not previously available were beyond the scope of this study. Therefore, the simulation model described by Vecchia (2002) was modified and used in this study to provide stochastic simulations of potential future water levels for Devils Lake and Stump Lake. Inputs to the simulation model include monthly estimates of precipitation, evaporation, and inflow for Devils Lake and Stump Lake.

Monthly water-balance equations for Devils Lake and Stump Lake for 2000-2007 take the following form:

$$
\begin{aligned}
V_{D L}(t)= & V_{D L}(t-1)+(1 / 12)[P(t)-E(t)] A_{D L}(t-1) \\
& +Q_{D L}(t)-Q_{D L>S L}(t)+e_{D L}(t) \\
V_{S L}(t)= & V_{S L}(t-1)+(1 / 12)[P(t)-E(t)] A_{S L}(t-1) \\
& +Q_{S L}(t)+Q_{D L>S L}(t)+e_{S L}(t),
\end{aligned}
$$

where

$$
\begin{aligned}
& V_{D L}(t) \quad \text { is the total volume of Devils Lake at the end } \\
& \text { of month } t \text {, in acre-feet; } \\
& V_{S L}(t) \quad \text { is the total volume of Stump Lake at the end } \\
& \text { of month } t \text {, in acre-feet; } \\
& A_{D L}(t) \quad \text { is the surface area of Devils Lake at the end of } \\
& \text { month } t \text {, in acres; } \\
& A_{S L}(t) \quad \text { is the surface area of Stump Lake at the end of } \\
& \text { month } t \text {, in acres; } \\
& Q_{D L}(t) \quad \text { is total inflow to Devils Lake for month } t \text {, in } \\
& \text { acre-feet; } \\
& Q_{S L}(t) \text { is local inflow to Stump Lake for month } t \text {, in } \\
& \text { acre-feet; } \\
& Q_{D L>S L}(t) \quad \text { is flow from Devils Lake to Stump Lake for } \\
& \text { month } t \text {, in acre-feet; } \\
& P(t) \quad \text { is precipitation on the lake surface for } \\
& \text { month } t \text {, in inches; } \\
& E(t) \quad \text { is evaporation from the lake surface for } \\
& \text { month } t \text {, in inches; } \\
& e_{D L}(t) \quad \text { is the water-balance error for Devils Lake for } \\
& \text { month } t \text {, in acre-feet; and } \\
& e_{S L}(t) \quad \text { is the water-balance error for Stump Lake for } \\
& \text { month } t \text {, in acre-feet. }
\end{aligned}
$$

None of the terms in the water-balance equations 1 and 2 were known with certainty, so minimum variance, unbiased estimates (estimates for which the errors have a small variance and a mean of zero) were computed as follows. Monthly flows from Devils Lake to Stump Lake, $Q_{D L>S L}(t)$, were estimated by using streamflow for USGS gaging station 05056636 (Devils Lake outlet to Stump Lake near Lakota, N. Dak.; site 11, fig. 2; table 1). Monthly inflows for Devils Lake for 1950-99 were computed using USGS streamflow gaging stations 05056400 (Big Coulee near Churchs Ferry, N. Dak.),
05056270 (Big Coulee below Churchs Ferry, N. Dak.), 05056340 (Little Coulee near Leeds, N. Dak.), and 05056410 (Channel A near Penn, N. Dak.; sites 6-9, fig. 2; table 1). Most of the surface inflow to Devils Lake during 1950-99 could be computed by using data from those stations. By 1999, however, backwater from Devils Lake had reached Lakes Alice and Irvine and the control structure on Channel A, and the streamgages on Big Coulee and Channel A had been discontinued. Therefore, for 2000-2006, several upstream lakes (Lakes Alice and Irvine, Chain Lake, Mikes Lake, and Dry Lake) were considered part of Devils Lake and the inflows needed to be estimated by using a different method. Monthly inflows to Devils Lake for 2000-2006 thus were expressed by using the equation

$$
Q_{D L}(t)=M\left[f Q^{*}(t)+(1-f) Q^{*}(t-1)\right],
$$

where

$Q^{*}(t) \quad$ is total flow for month $t$ for USGS gages 05056060 (Mauvais Coulee Tributary no. 3 near Cando, N. Dak.), 05056100 (Mauvais Coulee near Cando, N. Dak.), 05056200 (Edmore Coulee near Edmore, N. Dak.), 05056215 (Edmore Coulee Tributary near Webster, N. Dak.), 05056239 (Starkweather Coulee near Webster, N. Dak.), and 05056340 (Little Coulee near Leeds, N. Dak.; sites 1, 2, 3, 4, 5, and 7, fig. 2; table 1);

$M>0 \quad$ is a multiplier to be estimated as described later; and

$f(0 \leq f \leq 1) \quad$ is a fraction to be estimated as described later.

Use of equation 3 was motivated by several considerations. A weighted sum of the current and previous month's streamflows for the upstream stations was used because a time delay was expected to occur between the time flows passed the upstream stations and the time those flows became part of Devils Lake. Therefore, it was reasonable to assume that part of the current month's streamflow, namely $(1-f) Q^{*}(t)$, does not reach the lake until the following month. The multiplier, $M$, was expected to be greater than one because there is a considerable fraction of the total Devils Lake drainage area that is not tributary to one of the upstream stations. For example, the Calio, St. Joe, and Comstock Coulee drainage areas (fig. 2) and other small drainage areas adjacent to Devils Lake were not gaged. An intercept term was not included in equation 3 because previous studies indicated ground-water inflow or outflow for Devils Lake was negligible (Wiche and Pusc, 1994; Vecchia, 2002).

Precipitation and evaporation $(P(t)$ and $E(t)$, equations 1 and 2) were estimated by multiplying monthly precipitation and potential evapotranspiration for the National Weather Service station at Devils Lake (High Plains Regional Climate Center, 2006) by the monthly coefficients from table 2 . Because precipitation data from the same station used by 
Table 1. Selected U.S. Geological Survey gaging stations in the Devils Lake Basin

[USGS, U.S. Geological Survey]

\begin{tabular}{ccl}
\hline $\begin{array}{c}\text { Map number } \\
\text { (fig. 2) }\end{array}$ & $\begin{array}{c}\text { USGS gaging } \\
\text { station number }\end{array}$ & \multicolumn{1}{c}{ Station name } \\
\hline 1 & 05056060 & Mauvais Coulee Tributary no. 3 near Cando, N. Dak. \\
2 & 05056100 & Mauvais Coulee near Cando, N. Dak. \\
3 & 05056200 & Edmore Coulee near Edmore, N. Dak. \\
4 & 05056215 & Edmore Coulee Tributary near Webster, N. Dak. \\
5 & 05056239 & Starkweather Coulee near Webster, N. Dak. \\
6 & 05056270 & Big Coulee below Churchs Ferry, N. Dak. \\
7 & 05056340 & Little Coulee near Leeds, N. Dak. \\
8 & 05056400 & Big Coulee near Churchs Ferry, N. Dak. \\
9 & 05056410 & Channel A near Penn, N. Dak. \\
10 & 05056500 & Devils Lake near Devils Lake, N. Dak. \\
11 & 05056636 & Devils Lake outlet to Stump Lake near Lakota, N. Dak. \\
\hline
\end{tabular}

Table 2. Monthly multipliers applied to precipitation and potential evapotranspiration data from the Devils Lake National Weather Service station to obtain estimated precipitation and evaporation for the Devils Lake water-balance model.

\begin{tabular}{lcc}
\hline \multicolumn{1}{c}{ Month } & Multiplier for precipitation & Multiplier for evaporation \\
\hline January & 1.172 & 0 \\
February & 1.322 & 0 \\
March & 1.346 & 0 \\
April & 1.222 & .262 \\
May & 1.062 & .498 \\
June & 1.000 & .724 \\
July & 1.070 & .669 \\
August & 1.174 & .726 \\
September & 1.191 & .851 \\
October & 1.103 & .701 \\
November & 1.010 & .543 \\
December & 1.029 & 0 \\
\hline
\end{tabular}

Vecchia (2002) were used in this report, the monthly coefficients for precipitation are the same as the coefficients given in table 2 of that report. However, pan evaporation data used to compute earlier estimates of $E(t)$ were no longer available for 2000-2006. Therefore, the coefficient for $E(t)$ for a particular month was computed so that the average of the estimated lake evaporation for that month for 2000-2006 was equal to the average lake evaporation for that month for 1980-99 (as estimated using the previous methods). Because 1980-2006 was a homogeneous climatic period as shown later, lake evaporation for 2000-2006 was assumed to be similar to lake evaporation for 1980-99.
The values used for $M$ and $f$ in equation 3 were selected to minimize the sum of the squared errors [the $e_{D L}(t)$ 's in equation 1], subject to the constraint that the average error equals zero. The resulting estimates were $M=1.57$ and $f=0.87$, so equation 3 can be written

$$
Q_{D L}(t)=1.57\left[0.87 Q^{*}(t)+0.13 Q^{*}(t-1)\right] .
$$

The fitted monthly volume changes for Devils Lake during 2000-2006 based on estimates from equation 1, $V_{D L}(t)-V_{D L}(t-1)-e_{D L}(t)$, are plotted versus the measured volume changes, $V_{D L}(t)-V_{D L}(t-1)$, in figure 4 . The water-balance 
model provided a good fit to the measured monthly volume changes for 2000-2006. There was no systematic deviation of the measured volume changes from the fitted volume changes, and the magnitude of the errors was reasonable. Considering the fact that Devils Lake covers about 120,000 acres, a 1-inch error in $P(t)-E(t)$ translates into a 10,000 -acre-foot error in the calculated water balance.

As a cross-check to see if equation 4 was reasonable, the same equation was used to compute estimated inflow to Devils Lake for 1994-97 for comparison with the total flow for Big Coulee near Churches Ferry and Channel A near Penn (fig. 2) for that time period. The period 1994-97 was used because all the gaging stations for the upstream tributaries and the downstream tributaries were operating during that time. Average annual inflow for 1994-97 computed by using equation 4 was 285,000 acre-feet per year, and average annual flow for Big Coulee and Channel A for 1994-97 was 267,000 acre-feet per year. The difference $(18,000$ acre-feet per year) is consistent with net evaporation loss that would be expected for that time from the upstream chain of lakes. The upstream lakes were full during 1994-97 and their total surface area was about 24,000 acres. Therefore, 18,000 acre-feet per year corresponds to about 9 inches of net evaporation per year.

Local inflow to Stump Lake could not be estimated directly because of the lack of gaging stations in the Stump

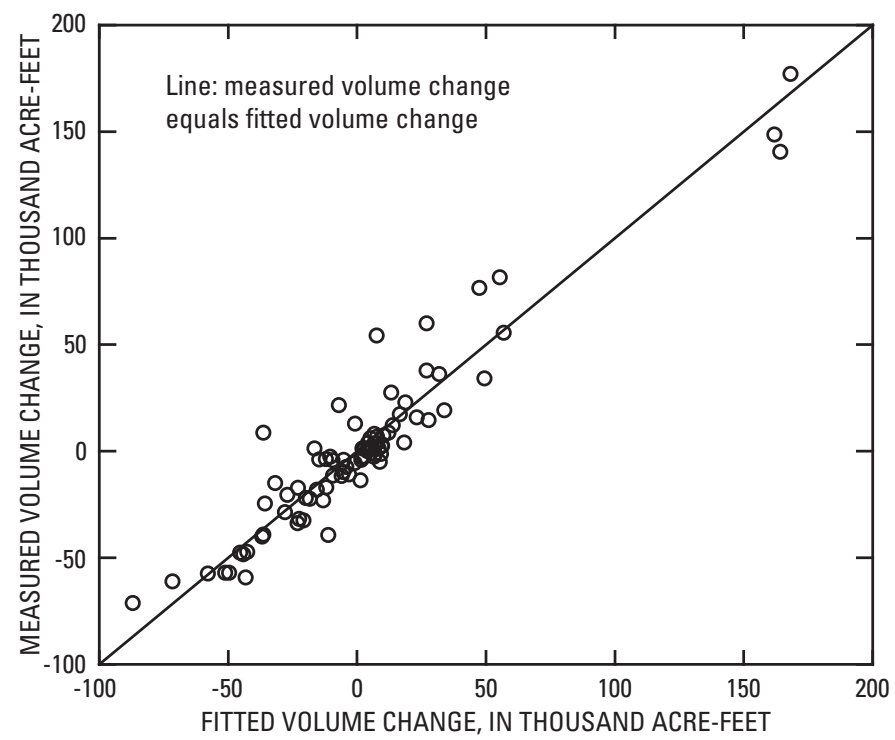

Figure 4. Measured monthly volume changes for Devils Lake for 2000-2006 and fitted volume changes from the water massbalance model.
Lake subbasin. Therefore, local inflows to Stump Lake were estimated from Devils Lake inflows as described by Vecchia (2002):

$$
Q_{S L}(t)=200+0.046 Q_{D L}(t)
$$

The intercept represents an estimated ground-water inflow of 200 acre-feet per month, which is added to 4.6 percent of Devils Lake inflow to obtain estimated Stump Lake inflow. Comparison of the fitted and measured volume changes for Stump Lake for 2000-2006 (fig. 5) indicated a reasonable fit. Although there were some relatively large errors considering the size of Stump Lake (about 12,000 acres), the errors were small in relation to the combined volume of Devils Lake and Stump Lake. Therefore, potential errors in computing Stump Lake inflows were expected to have a negligible effect on the combined water-balance for Devils Lake and Stump Lake.

Estimated monthly precipitation, evaporation, and inflow values for Devils Lake for 2000-2006, obtained as described previously, are provided in the appendix. Annual inputs for 2000-2006, obtained by summing the estimated monthly inputs, are shown in figures 6-8 along with previously computed annual inputs for 1950-99. The next two sections of the report discuss statistical properties of the model input data and some important implications for flood-risk analysis for Devils Lake and Stump Lake.

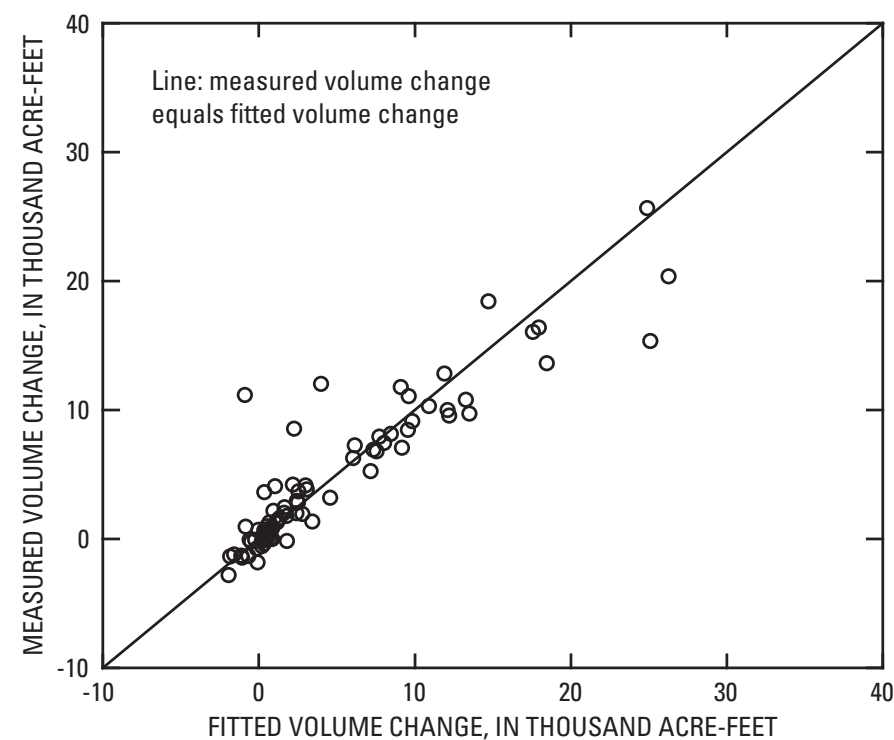

Figure 5. Measured monthly volume changes for Stump Lake for 2000-2006 and fitted volume changes from the water massbalance model. 


\section{Statistical Properties of Model Input Data}

Devils Lake and Stump Lake receive surface runoff from a large basin, and evaporation is the only major water-loss mechanism unless water levels are above the spill elevation to the Sheyenne River. Therefore, water in the lakes at the present time (2007) depends on past inflow, precipitation, and evaporation all the way back to the last time Devils Lake was essentially empty (1940). Thus, long-term climatic conditions in the basin have a much larger effect on lake levels than yearto-year changes in precipitation or evaporation. By contrast, a riverine flood commonly depends on short-term precipitation events, such as the summer rains of 1993 or the winter blizzards of 1996-97, as the primary sources of flooding. For example, the highest recorded annual inflow to Devils Lake occurred during 1997 and consisted of about 540,000 acrefeet (fig. 8). During that year, record floods occurred on many rivers and streams throughout the Red River Basin, including the Devils Lake Basin. However, the 1997 inflow comprised only about 16 percent of the total inflow for 1993-2006 (about 3.5 million acre-feet). On the basis of equation 5, an estimated 193,000 acre-feet of local inflow to Stump Lake occurred during 1993-2006. When added to Devils Lake inflow, the total inflow to Devils Lake and Stump Lake during 1993-2006 was about 3.7 million acre-feet. As mentioned previously, the combined volume of Devils Lake and Stump Lake increased by about 2.3 million acre-feet from 1992 through the present (2007). The difference of 1.4 million acre-feet (3.7-2.3) was the amount of net evaporative loss from the lakes during 1993-2006.

The previous discussion indicates the importance of understanding climatic and hydrologic variability in the Devils Lake Basin before analyzing flood risk. As indicated by figure 6, precipitation for 1950-79 averaged about 18.3 inches per year, compared to about 22.4 inches per year for 1980-2006. The increase of 4.1 inches per year is highly significant from a statistical standpoint: a two-sample t-test (Devore, 1987) for equality of the two means yielded a p-value of 0.0006 . In other words, there is only about a 6 in 10,000 chance of obtaining such a large difference between the two means if there is no change in precipitation patterns. Generally, a p-value less than 0.01 indicates a highly significant difference. Thus, there is strong evidence for an abrupt change in Devils Lake precipitation in about 1980. This change is in agreement with a regional pattern of change detected by Garbrecht and Rossel (2002), in which an abrupt trend toward higher precipitation occurred in parts of Minnesota, North Dakota, and South Dakota during 1980-99. Furthermore, Garbrecht and Rossel (2002) analyzed precipitation patterns from 1895-1999 and found no significant changes in precipitation before 1980. Judging by figure 6 , the increase in precipitation occurred primarily in July-December when there tended to be a much higher frequency of wet conditions during 1980-2006 than during 1950-79. In fact, 15 of the 18 wettest
July-December seasons during 1950-2006 occurred during 1980-2006.

Lake evaporation also increased from 1950-79 to 1980-2006, but by a much smaller amount than precipitation (fig. 7). Evaporation during 1950-79 averaged 29.6 inches per year, compared to 30.9 inches per year during 1980-2006. The increase is not statistically significant (the p-value for a two-sample t-test was 0.07 ) and was due primarily to a string of very high evaporation years during the extreme drought of 1988-90. During those years, lake evaporation averaged 37.1 inches and precipitation averaged 17.9 inches, so net evaporation averaged more than 19 inches per year.

Unlike precipitation, lake inflows did not increase until 1993 (fig. 8). Inflows during 1950-92 averaged only 33,800 acre-feet per year, compared to 244,200 acre-feet per year for 1993-2006. [Note that the annual inflow estimates given in this report may differ from estimates obtained using alternate water-balance equations. For example, Wiche and others (2000) obtained an estimated average annual inflow of 60,100 acre-feet for 1950-92, compared with 33,800 acrefeet in this report. Small changes in estimated precipitation or evaporation can lead to substantial changes in estimated annual inflow for a large lake such as Devils Lake.] The long lag between the onset of wetter conditions in about 1980 and the more than sevenfold increase in inflow during 1993-2006 can be attributed to the unusual hydrologic conditions of the Devils Lake Basin (Vecchia, 2002). Much of the increase in precipitation during 1980-87 probably went toward filling soil moisture deficits, the upstream chain of lakes, and the thousands of smaller lakes and wetlands in the upper basin; thus little of the precipitation reached Devils Lake as runoff. Then, the extreme drought of 1988-90 delayed the onset of higher flows until the summer flood of 1993, which filled most of the lakes and wetlands in the upper basin. Once most of the available storage in the upper basin was filled, inflow to Devils Lake increased dramatically. Runoff for the 3,320-square-mile Devils Lake Basin averaged only about 0.2 inch per year during 1950-92, compared to about 1.4 inches per year during 1993-2006.

Although a definitive cause for the change in precipitation in 1980 is not known, it is likely related to sea-surface temperature anomalies and atmospheric-pressure anomalies in the Pacific and Atlantic Oceans (Wiche and others, 2000), including the El Niño/Southern Oscillation (ENSO), the Pacific Decadal Oscillation (PDO), and the Atlantic Multidecadal Oscillation (AMO). Recent discussions of the effects of these anomalies on North American climate can be found in Enfield and Cid-Serrano (2006); Schwierz and others (2006); Shabbar (2006); and McCabe and others (2007). Unfortunately, the complex nature of the interactions between the various anomalies and the geographic location of the Devils Lake Basin seems, at least at present, to make future long-term projections of precipitation in the Devils Lake Basin of limited use. 


\section{Long-Term Climate Variability for Devils Lake}

Although future precipitation may be unpredictable, there is mounting evidence that long-term climate variation follows some interesting probabilistic structure that can be exploited. In particular, long-term climate reconstructions based on tree rings or lake sediments (Vance and others, 1992; Shapley and others, 2005) indicate that climate in the Northern Great Plains has consisted of relatively long dry periods interspersed with wet periods, that the transitions from dry to wet or wet to dry are relatively abrupt (that is, little time elapses between the dry and wet states), and that the durations of the individual dry or wet periods are highly variable and seemingly random. Climate modeling research also indicates that coupled global ocean-temperature, atmospheric-circulation, and terrestrialfeedback mechanisms can lead to multiple "equilibrium" climate states with abrupt transitions between states (Demaree and Nicolis, 1990; Yonetani and Gordon, 2001; Wang, 2004). Furthermore, physical considerations support the existence of either one or two primary equilibrium states because more than two states tend to result in rapid transitions between states and continuation in any one state for an extended period of time is improbable (Demaree and Nicolis, 1990). The highenergy state (the wet state) generally has shorter duration, on average, and more variability from year to year than the lowenergy state (the dry state).
The previous discussion points to a rather interesting possibility with regard to Devils Lake precipitation (fig. 6). Climatic conditions in the Devils Lake Basin in the distant past and the near future may consist of two equilibrium climate states: a dry state similar to 1950-79 and a wet state similar to 1980-2006. Existence of any intermediate states, or more extreme dry or wet states, is unlikely. Further evidence of the plausibility of this assumption was given by Vecchia (2002), who showed that the geologic history of lake-level fluctuations for Devils Lake for the past 5,000 years (Bluemle, 1996) is consistent with a two-state climate model with random transitions between states. He estimated that the average duration of the dry states (or "normal" states, similar to conditions in 1950-79) was 120 years and the average duration of the wet states (similar to conditions in 1980-99) was 20 years. The average duration of the wet states is a key parameter for evaluating future flood risk for Devils Lake. Therefore, that parameter was updated for this study using the longer period (1980-2006) to represent the wet state and using a more detailed analysis based on the model of Demaree and Nicolis (1990).

The new estimation results, described in the appendix, indicate that an average duration of 30 years for the wet states and 120 years for the dry states best matched the historical evidence from long-term climate reconstructions in the region. The average recurrence interval of the wet periods

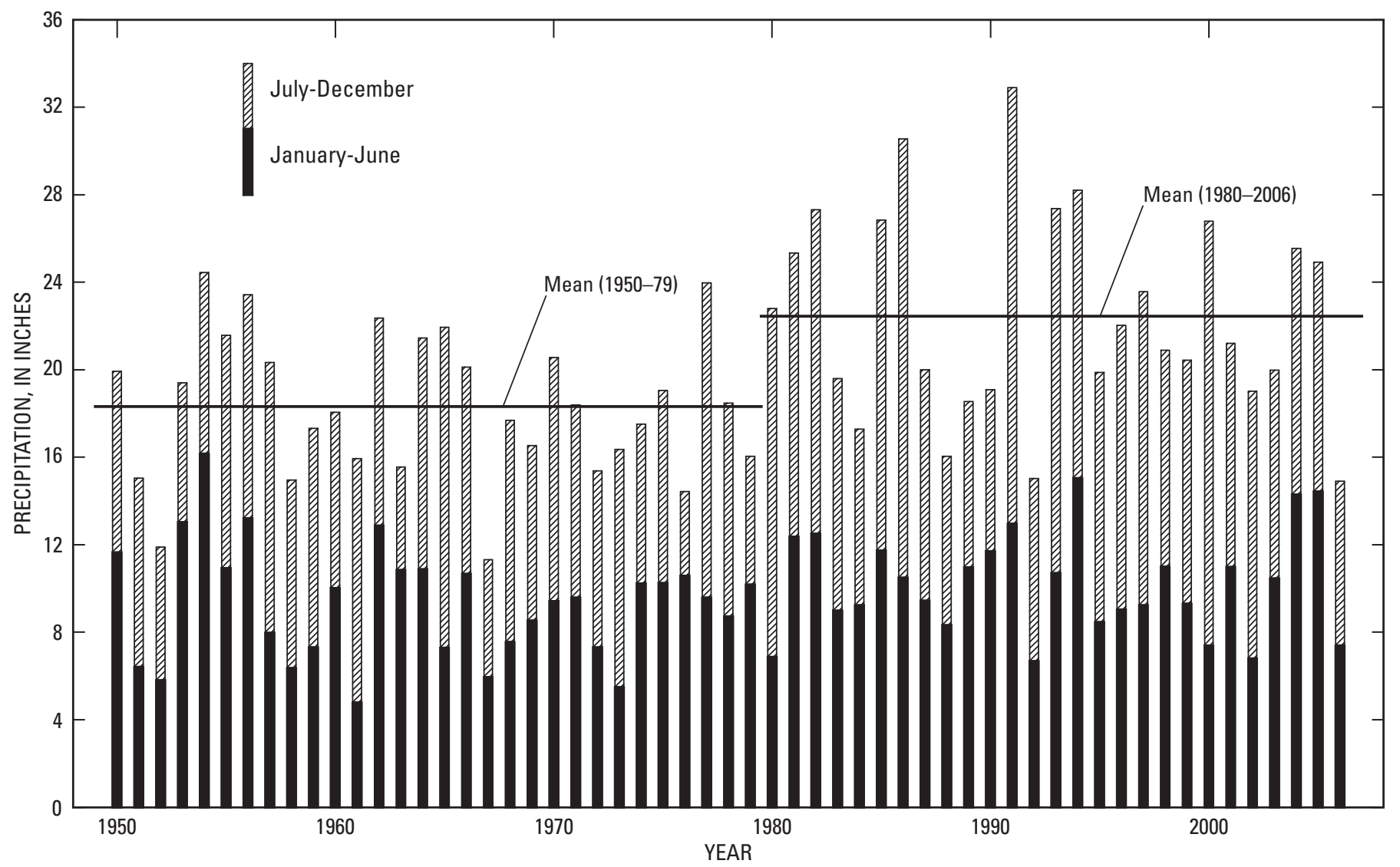

Figure 6. Estimated annual precipitation for Devils Lake for 1950-2006. 


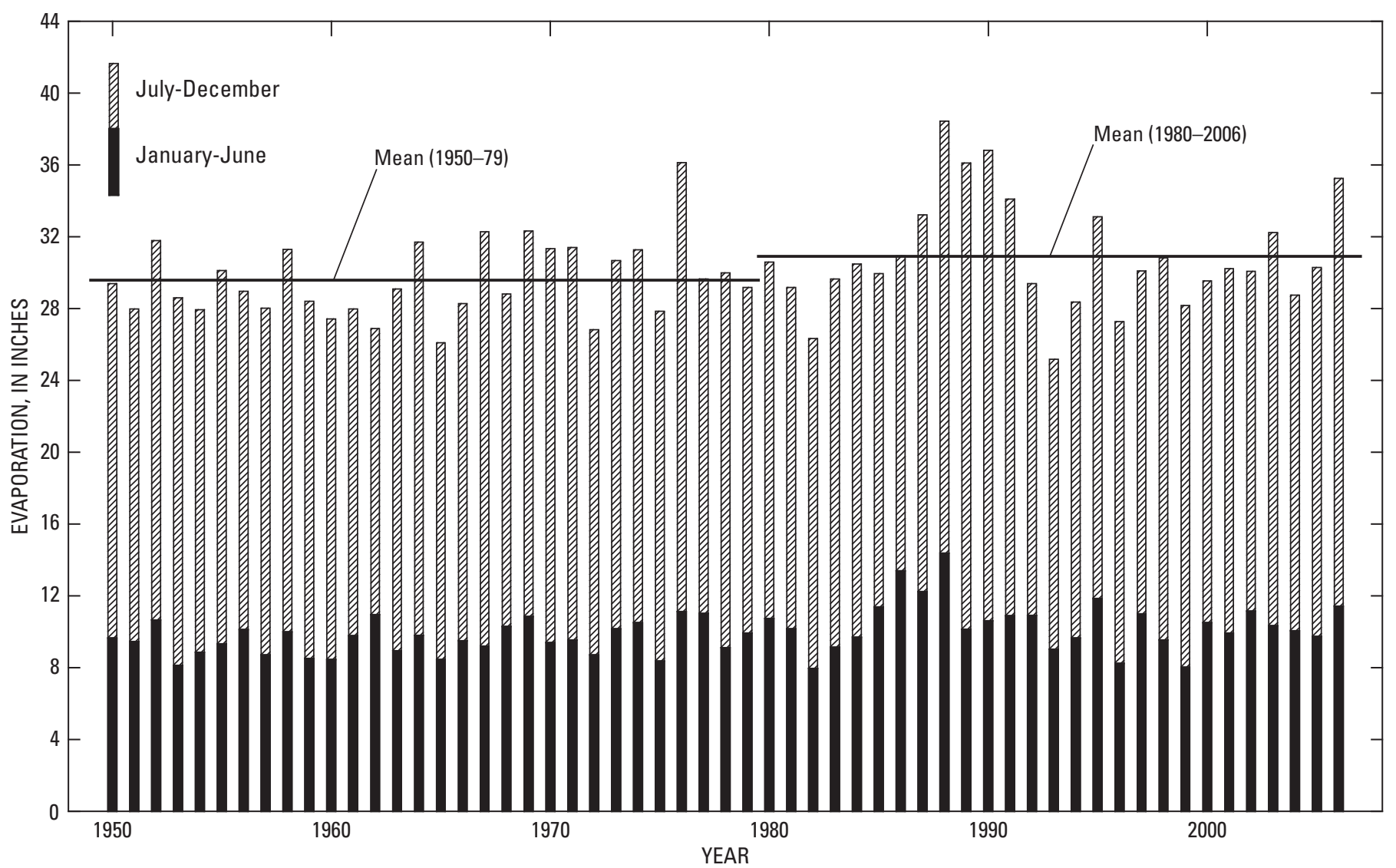

Figure 7. Estimated annual evaporation for Devils Lake for 1950-2006.

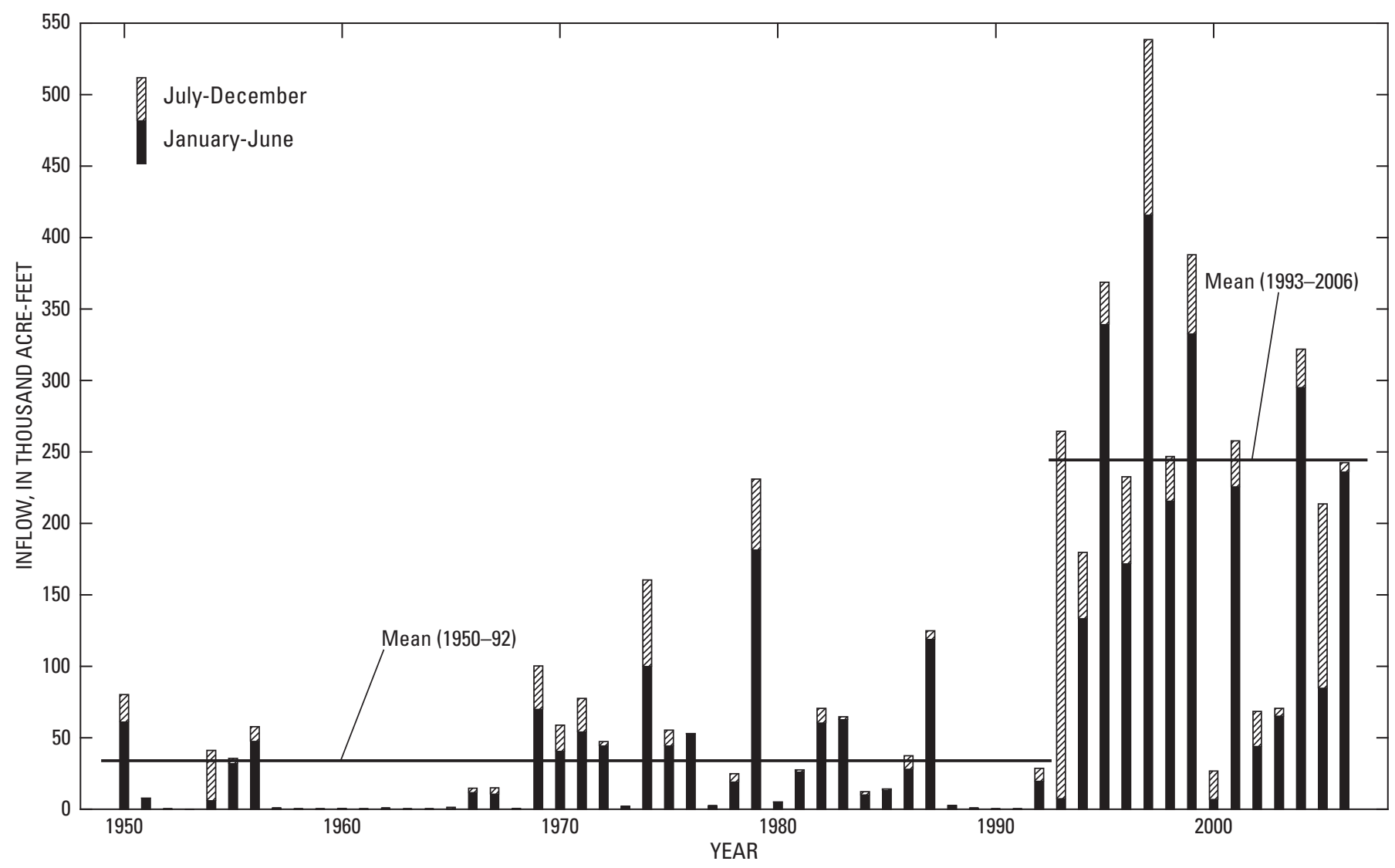

Figure 8. Estimated annual inflow for Devils Lake for 1950-2006. 
(the time from the start of one wet period to the start of the next wet period) was 150 years, which is in agreement with Shapley and others (2005), who estimated an average recurrence interval of 140-160 years by using tree-ring and lake-sediment records. An example of a simulated precipitation record with a length of 1,500 years (a small segment of a much longer record of 50,000 years; see appendix) is shown in figure 9. There were 10 wet periods (shaded in gray) during the 1,500-year simulation period, so the average recurrence interval for this example was equal to the expected long-term average of 150 years. The average duration of the wet periods for this example was 32 years and the average duration of the dry periods was 145 years, both of which are somewhat higher than the long-term averages of 30 years and 120 years. However, there was a large range in the durations of the individual intervals - the wet periods ranged from 3 to 80 years in duration and the dry periods ranged from 15 to 367 years in duration.

The simulated precipitation data have a peculiar property commonly observed in nature - the number of years remaining until a particular wet (or dry) period ends has the same probability distribution no matter how long the wet (or dry) period has already lasted (Demaree and Nicolis, 1990). Therefore, the 27-year duration (1980-2006) of the current wet period for the Devils Lake Basin has no influence on the remaining length of the period. In particular, the probability distribution of the number of years remaining in the current wet period is

$$
\operatorname{Prob}[Y>k]=\exp (-k / 30)
$$

where Prob[.] denotes the probability of the event in brackets, $Y$ is the remaining length of the current wet period, in years, and $k$ is any non-negative integer. For example, there is a 72-percent chance the current wet cycle will last at least another 10 years ( $\operatorname{Prob}[Y>10])$, a 37-percent chance it will last at least another 30 years, and a 14-percent chance it will last at least another 60 years. Therefore, it is not likely the current wet cycle will end any time soon, and there is better than a 1-in-3 chance it will last at least another 30 years.

\section{Stochastic Simulation of Climate and Lake Levels for Devils Lake}

The simulation model developed by Vecchia (2002) was modified as described in the appendix to generate potential future realizations, or traces, of monthly Devils Lake precipitation, evaporation, and inflow and resulting lake levels and sulfate concentrations for Devils Lake and Stump Lake for 2008-40. Sulfate concentrations were required along with lake levels because the North Dakota Devils Lake Emergency Outlet (North Dakota State Water Commission, 2007) is designed to control the amount of water discharged from Devils Lake in accordance with downstream sulfate standards in the Sheyenne River receiving waters. The assumptions used for operation of the emergency outlet are described in the appendix.
The stochastic simulations were generated by using initial conditions existing on September 30, 2007. The only variables required to initialize the model were the starting lake levels for Devils Lake and Stump Lake (1,447.1 feet), the estimated amount of Devils Lake inflow for September 2007 $(2,315$ acre-feet), the starting sulfate concentrations for each of the bays of Devils Lake (see appendix), and the current climate state (wet). A time series model was used to generate future sequences of monthly precipitation and evaporation for Devils Lake that had the same statistical properties (such as means, variances, serial correlations) as the historical data for either 1950-79 or 1980-2006, depending on whether the climate state was dry (1950-79) or wet (1980-2006). Then, the generated precipitation and evaporation data were used to generate monthly inflows, and the combined monthly input data were used in a water and sulfate mass-balance model to simulate monthly lake levels and sulfate concentrations for Devils Lake and Stump Lake, streamflow and sulfate concentrations for the Sheyenne River receiving waters, and outlet discharges for the emergency outlet.

Because of the current (2007) high water levels, the remaining duration of the current wet period is by far the most important consideration for evaluating future risk. To demonstrate, two sets of simulation runs with 1,000 traces each were generated by using a fixed duration for the wet period of 2 more years for the first set and 30 more years for the second set. Each trace was based on randomly generated possible future time series of precipitation, evaporation, and inflow that were consistent with the assumed duration of the wet period. The recorded annual maximum lake levels for 1950-2007, along with examples of 10 (out of the 1,000) future lake level traces for 2008-40 are shown in figures 10 and 11. The 5th, 50th, and 95th percentiles of the generated lake levels for each year, computed from all 1,000 simulated traces, also are shown. For the simulations with the wet period lasting 2 more years (fig. 10), most (90 percent) of the simulated lake levels in 2010 were between about 1,444 and 1,452 feet. After the wet period ended, however, lake levels steadily declined and in 2040, most of the traces were between about 1,420 and 1,440 feet. For the simulations with the wet period lasting 30 more years (fig. 11), the simulated lake levels were highly variable and the median lake level declined only slightly from 2008 through 2040. In 2040, most of the traces were between about 1,434 and 1,456 feet. Thus, if wet conditions continue, lake levels could well increase more than 10 feet during the next 10 years, or lake levels could well decline several feet during the next 10 years before rising again to 1,456 feet or higher during subsequent decades.

Because it was impossible to predict exactly how long the current wet cycle will continue, the risk analysis results in the next section are based on a weighted average over all possible future climate conditions. A total of 10,000 simulated traces were generated from the stochastic model, in which each trace represents one possible future realization based on randomly generated climate states and randomly generated time series of precipitation, evaporation, and inflow that were consistent with 
the generated climate states. For each trace and each simulation year, the climate state was selected at random by using the climate transition model with 30 years average duration of the wet periods and 120 years average duration of the dry periods. On the basis of the previous results from equation 6 , 72 percent $(7,200)$ of the traces have the wet cycle lasting at least another 10 years, 37 percent $(3,700)$ of the traces have the wet cycle lasting at least another 30 years, and 14 percent $(1,400)$ of the traces have the wet cycle lasting at least another 60 years.

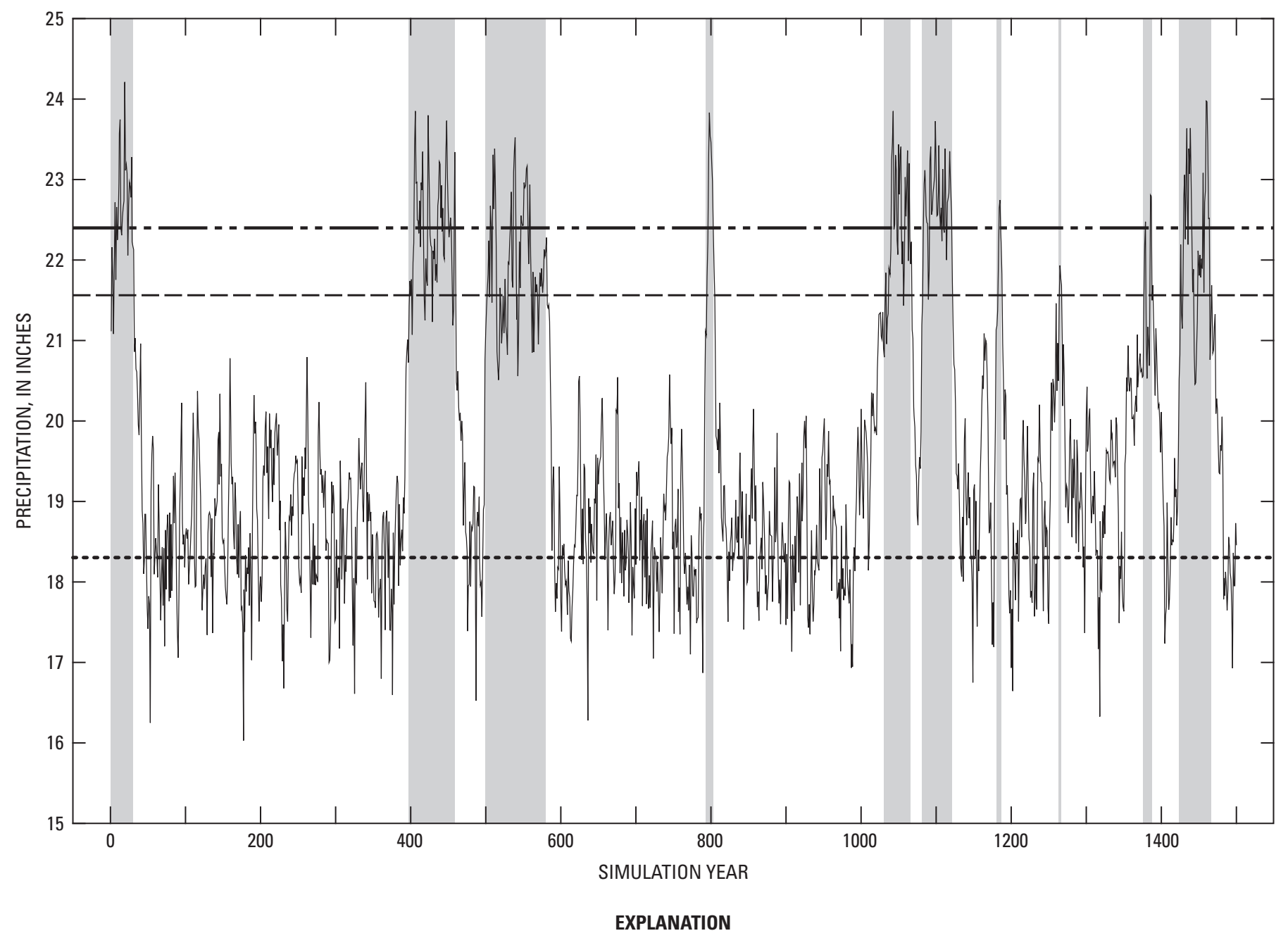

Distinct wet periods

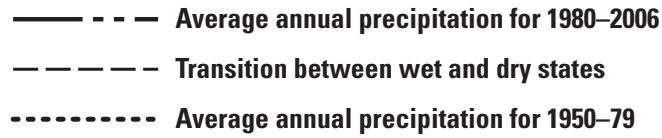

Figure 9. Five-year moving average of annual precipitation for 1,500 years generated from the climate transition model with 30-year average duration of the wet periods (similar to 1980-2006) and 120-year average duration of the dry periods (similar to 1950-79). 


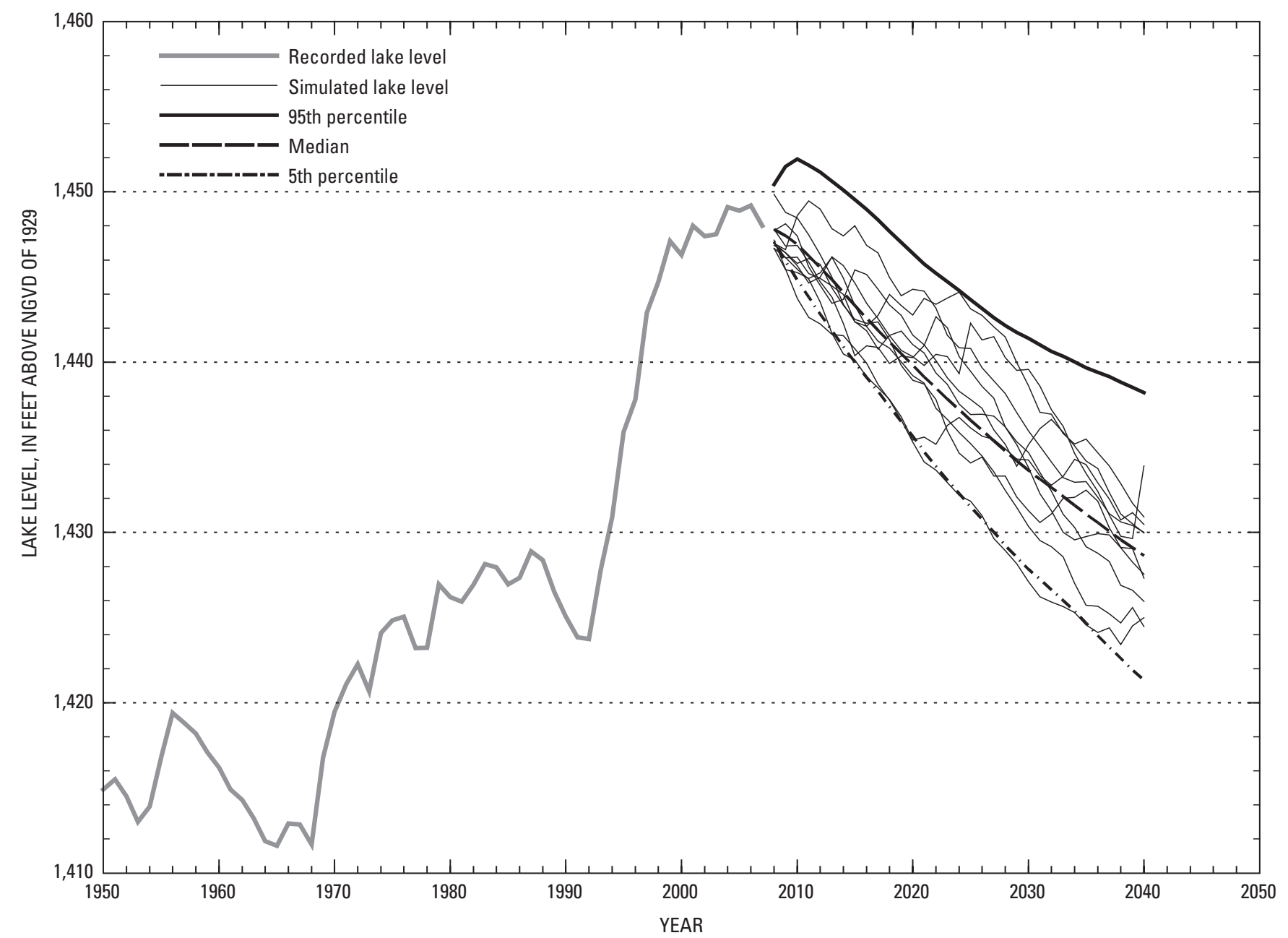

Figure 10. Historical and generated annual maximum lake levels for Devils Lake for 1950-2040, assuming the current wet period lasts until 2010. 


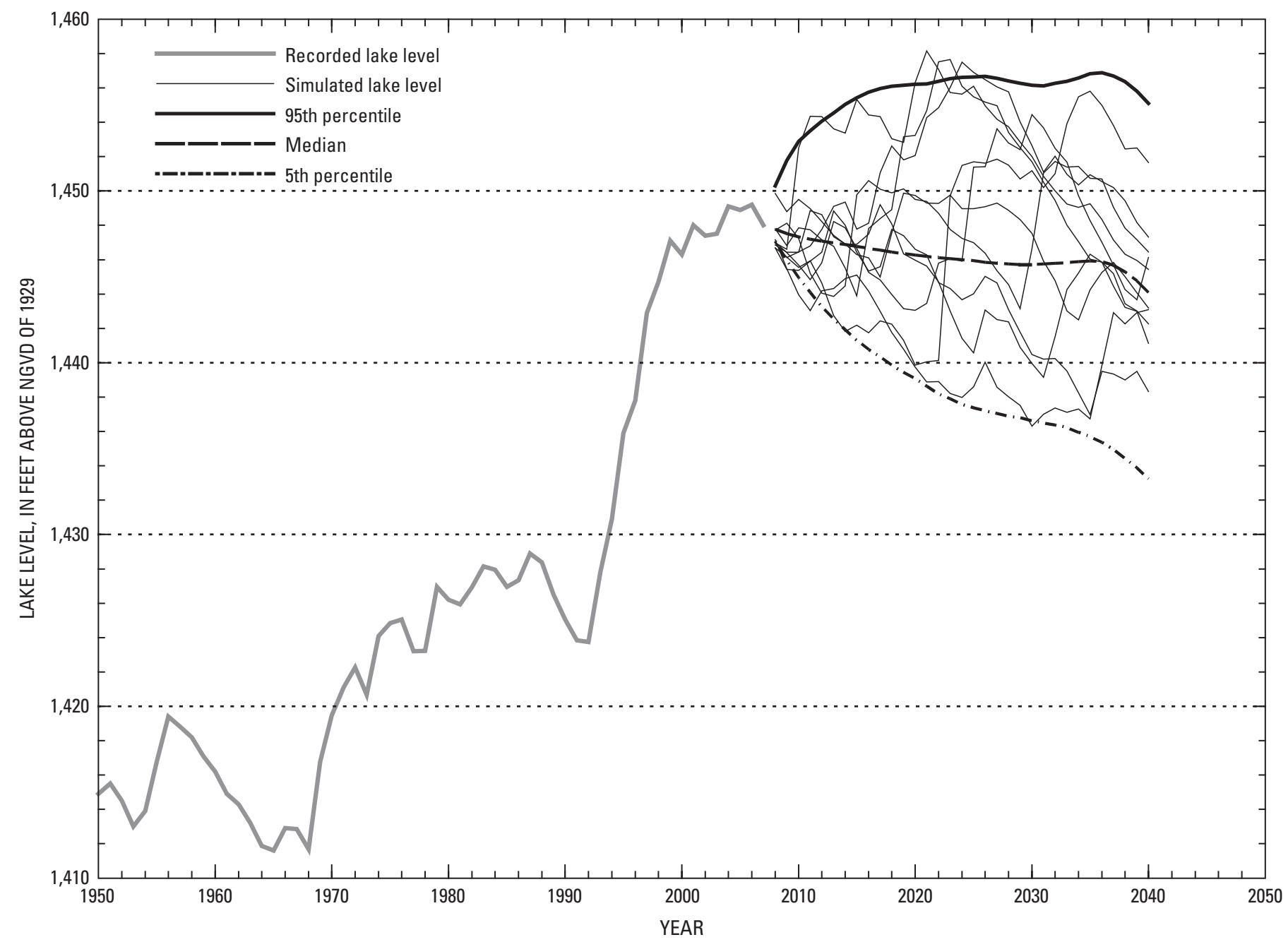

Figure 11. Historical and generated annual maximum lake levels for Devils Lake for 1950-2040, assuming the current wet period lasts until 2038. 


\section{Flood Risk Analysis for Devils Lake}

For riverine floods, a key parameter for flood-insurance rate maps is the so-called 100-year flood elevation, which is the water level that is exceeded once every 100 years, on average. It is generally assumed that the annual maximum water level obtained at a particular river cross-section has the same probability distribution every year and that the maximum water level for a particular year is statistically independent of all past or future annual maximum water levels. Under these assumptions, the average recurrence interval of a flood (the average length of time between any two successive floods) is the reciprocal of the annual exceedance probability,

$$
R I(h)=1 / P(h),
$$

where
$h$ is a specified elevation, in feet;
$R I(h) \quad$ is the recurrence interval, in years, associated with elevation $h$; and
$P(h) \quad$ is the probability of exceeding elevation $h$ in any given year.

The 100-year flood elevation, $h_{100}$, is the value of $h$ for which $R I\left(h_{100}\right)=100$ and $P\left(h_{100}\right)=0.01$. The actual amount of time until the next 100-year flood (starting this year, for example) is a random variable with a mean of 100 years and a probability distribution given by

$$
\operatorname{Prob}[X>k]=(0.99)^{k},
$$

where

$X \quad$ is the time, in years, until the next 100-year flood; and

$k=0,1,2, \ldots \quad$ is any non-negative integer.

Equation 8 holds because the event $[X>k]$ is equivalent to the event that no 100-year flood occurs in each of the next $k$ years, which with the previous assumptions equals $(0.99)^{k}$. The event $[X>k]$ also is equivalent to the event that the maximum elevation obtained during the next $k$ years is less than the 100-year flood elevation, therefore

$$
\operatorname{Prob}\left[H_{k}<h_{100}\right]=(0.99)^{k}=(1-1 / 100)^{k},
$$

where

$$
\begin{aligned}
& H_{k} \quad \text { is the maximum elevation obtained during the } \\
& \text { next } k \text { years. }
\end{aligned}
$$

Equation 9 can be expressed in a more general form,

$$
\operatorname{Prob}\left[H_{k}<h_{100 / A E P}\right]=(1-A E P / 100)^{k},
$$

where

$$
A E P \quad \text { is the annual exceedance probability, in }
$$
percent.
A key observation regarding equation 10 is that, for riverine floods, $h_{100 / A E P}$ is assumed to not depend on the number of future years, $\mathrm{k}$, or on the starting year. However, for Devils Lake (or any closed lake), the probability distribution of the maximum lake level for future years is highly dependent on the starting lake level. Therefore, analogous with equation 10, the flood elevation for Devils Lake for a given annual exceedance probability was defined in this report as follows:

$$
\operatorname{Prob}\left[H_{k}(2008)<h_{k, 100 / A E P}(2008)\right]=(1-A E P / 100)^{k},
$$

where

$H_{k}(2008) \quad$ is the maximum level of Devils Lake during 2008 to $2008+k-1$;

$h_{k, 100 / A E P}(2008)$ is the flood elevation for 2008 to $2008+k-1$; and

$A E P \quad$ is the annualized exceedance probability, in percent.

Equation 11 was developed for use in determining flood-insurance rate maps (FIRMs) for Devils Lake that are analogous to FIRMs for rivers, which are based on a specified annual exceedance probability, such as 1 percent. For other purposes, such as planning road or levee raises, cumulative flood elevations are also useful. Cumulative flood elevations for Devils Lake are defined as follows:

$$
\operatorname{Prob}\left[H_{k}(2008)<h_{k}^{*}(2008)\right]=1-C E P / 100,
$$

where

$h_{k}^{*}(2008) \quad$ is the cumulative flood elevation for 2008 to $2008+k-1$; and

CEP is the cumulative exceedance probability, in percent.

The cumulative exceedance probability is the probability of exceeding a given elevation sometime during the next $k$ years, and the annual exceedance probability is the average probability of exceeding a given elevation in any one of the next $k$ years. Therefore, cumulative flood elevations generally are higher than corresponding flood elevations with $A E P=C E P$.

Cumulative flood elevations for Devils Lake for 2008-40 ( $k=1$ to 33 ), computed by using 10,000 lake level traces described previously, indicate there is a relatively high risk of much higher lake levels occurring in future years (fig. 12 and table 3). For example, there is about a 1-percent chance of exceeding 1,459.9 feet ( 0.9 foot above the spill elevation to the Sheyenne River), about a 5-percent chance of exceeding 1,455.7 feet, and about a 10-percent chance of exceeding 1,453.8 feet sometime between 2008 and 2015. In the nearer future, there is about a 1-percent chance of reaching 1,456.2 feet, about a 5-percent chance of reaching 1,452.8 feet, and about a 10-percent chance of reaching 1,451.2 feet sometime between 2008 and 2010. In the more distant future, there is about a 1-percent chance of reaching 1,461.8 feet, about a 5-percent chance of reaching 1,459.3 feet, and about a 


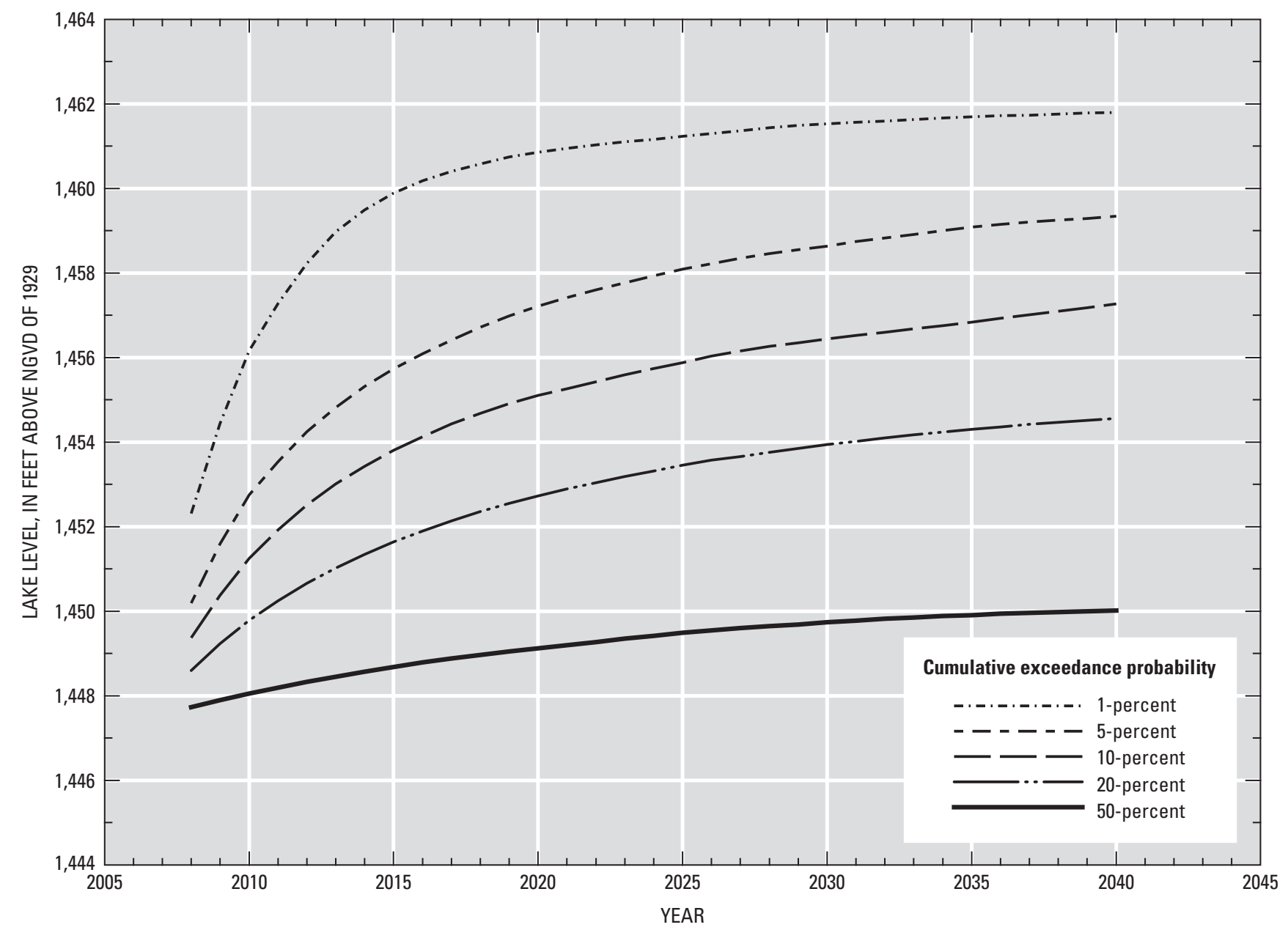

Figure 12. Cumulative exceedance elevations for Devils Lake for 2008-40, computed by using 10,000 traces from the Devils Lake stochastic simulation model (exceedance elevations are for calm conditions and open water).

10-percent chance of reaching 1,457.3 feet sometime between 2008 and 2040. Although the risk of greater lake levels is relatively high, the lake is by no means certain to rise more than another foot above the historical record level $(1,449.2$ feet in 2006). For example, there is about a 50-percent chance the lake will not exceed 1,450 feet any time between 2008 and 2040.

Flood elevations for 2008-40 corresponding with a 0.5-percent, 1-percent, and 2-percent annualized exceedance probability (equation 11) also were computed using the same 10,000 lake level traces (fig. 13 and table 4). For a 1-percent annualized exceedance probability, the flood elevation increases from about 1,452.3 feet in 2008 to about 1,454.6 feet in 2017 before declining. Thus, for 2008, a residence near Devils Lake at elevation 1,452.3 feet has about the same chance of being flooded as a residence on the edge of the 100-year flood plain for, say, the Red River at Fargo, N. Dak. However, when considering the next 10 years (2008-17), a residence near Devils Lake at elevation 1,454.6 feet has about the same chance of being flooded as a residence on the edge of the 100-year flood plain for the Red River at Fargo, N. Dak. The Devils Lake residence at 1,454.6 feet would be less likely to flood early in the 10-year period and more likely to flood later in the 10-year period than the residence on the Red River at Fargo, but the average risk over the 10-year period would be the same. Considering a 0.5-percent annualized flood risk (equivalent to a "200-year" riverine flood) and a 10-year time horizon (2008-17), the Devils Lake flood elevation would be $1,456.5$ feet; for a 2 -percent annualized flood risk (equivalent to a " 50 -year" riverine flood) and a 10 -year time horizon, it would be 1,452.5 feet. Note that these flood elevations for Devils Lake do not include the effects of ice or wind, which may increase the flood elevations for certain locations around the lake. The basic flood-elevation maps produced by FEMA for locations around the lake will include adjustments for the effects of wind and ice, and thus the published flood elevations for many locations may be higher than the elevations reported here. 
Table 3. Cumulative flood elevations for Devils Lake for 2008-40 for cumulative exceedance probabilities of 1, 5, 10,20 , and 50 percent.

[Flood elevations are for calm conditions and open water]

\begin{tabular}{|c|c|c|c|c|c|}
\hline \multirow{2}{*}{ Year } & \multicolumn{5}{|c|}{ Cumulative exceedance probability, in percent } \\
\hline & 1 & 5 & 10 & 20 & 50 \\
\hline 2008 & $1,452.3$ & $1,450.2$ & $1,449.4$ & $1,448.6$ & $1,447.7$ \\
\hline 2009 & $1,454.4$ & $1,451.6$ & $1,450.4$ & $1,449.2$ & $1,447.9$ \\
\hline 2010 & $1,456.2$ & $1,452.8$ & $1,451.2$ & $1,449.8$ & $1,448.0$ \\
\hline 2011 & $1,457.3$ & $1,453.5$ & $1,451.9$ & $1,450.2$ & $1,448.2$ \\
\hline 2012 & $1,458.2$ & $1,454.2$ & $1,452.5$ & $1,450.7$ & $1,448.3$ \\
\hline 2013 & $1,459.0$ & $1,454.8$ & $1,453.0$ & $1,451.0$ & $1,448.4$ \\
\hline 2014 & $1,459.5$ & $1,455.3$ & $1,453.4$ & $1,451.3$ & $1,448.6$ \\
\hline 2015 & $1,459.9$ & $1,455.7$ & $1,453.8$ & $1,451.6$ & $1,448.7$ \\
\hline 2016 & $1,460.2$ & $1,456.1$ & $1,454.1$ & $1,451.9$ & $1,448.8$ \\
\hline 2017 & $1,460.4$ & $1,456.4$ & $1,454.4$ & $1,452.1$ & $1,448.9$ \\
\hline 2018 & $1,460.6$ & $1,456.7$ & $1,454.7$ & $1,452.4$ & $1,449.0$ \\
\hline 2019 & $1,460.7$ & $1,457.0$ & $1,454.9$ & $1,452.6$ & $1,449.0$ \\
\hline 2020 & $1,460.8$ & $1,457.2$ & $1,455.1$ & $1,452.7$ & $1,449.1$ \\
\hline 2021 & $1,461.0$ & $1,457.4$ & $1,455.3$ & $1,452.9$ & $1,449.2$ \\
\hline 2022 & $1,461.0$ & $1,457.6$ & $1,455.4$ & $1,453.0$ & $1,449.3$ \\
\hline 2023 & $1,461.1$ & $1,457.8$ & $1,455.6$ & $1,453.2$ & $1,449.4$ \\
\hline 2024 & $1,461.2$ & $1,457.9$ & $1,455.7$ & $1,453.3$ & $1,449.4$ \\
\hline 2025 & $1,461.2$ & $1,458.1$ & $1,455.9$ & $1,453.4$ & $1,449.5$ \\
\hline 2026 & $1,461.3$ & $1,458.2$ & $1,456.0$ & $1,453.6$ & $1,449.6$ \\
\hline 2027 & $1,461.4$ & $1,458.4$ & $1,456.2$ & $1,453.7$ & $1,449.6$ \\
\hline 2028 & $1,461.4$ & $1,458.5$ & $1,456.3$ & $1,453.8$ & $1,449.6$ \\
\hline 2029 & $1,461.5$ & $1,458.6$ & $1,456.4$ & $1,453.8$ & $1,449.7$ \\
\hline 2030 & $1,461.5$ & $1,458.6$ & $1,456.4$ & $1,453.9$ & $1,449.7$ \\
\hline 2031 & $1,461.6$ & $1,458.7$ & $1,456.5$ & $1,454.0$ & $1,449.8$ \\
\hline 2032 & $1,461.6$ & $1,458.8$ & $1,456.6$ & $1,454.1$ & $1,449.8$ \\
\hline 2033 & $1,461.6$ & $1,458.9$ & $1,456.7$ & $1,454.2$ & $1,449.8$ \\
\hline 2034 & $1,461.7$ & $1,459.0$ & $1,456.8$ & $1,454.2$ & $1,449.9$ \\
\hline 2035 & $1,461.7$ & $1,459.1$ & $1,456.8$ & $1,454.3$ & $1,449.9$ \\
\hline 2036 & $1,461.7$ & $1,459.2$ & $1,456.9$ & $1,454.4$ & $1,449.9$ \\
\hline 2037 & $1,461.7$ & $1,459.2$ & $1,457.0$ & $1,454.4$ & $1,450.0$ \\
\hline 2038 & $1,461.8$ & $1,459.2$ & $1,457.1$ & $1,454.5$ & $1,450.0$ \\
\hline 2039 & $1,461.8$ & $1,459.3$ & $1,457.2$ & $1,454.5$ & $1,450.0$ \\
\hline 2040 & $1,461.8$ & $1,459.3$ & $1,457.3$ & $1,454.6$ & $1,450.0$ \\
\hline
\end{tabular}




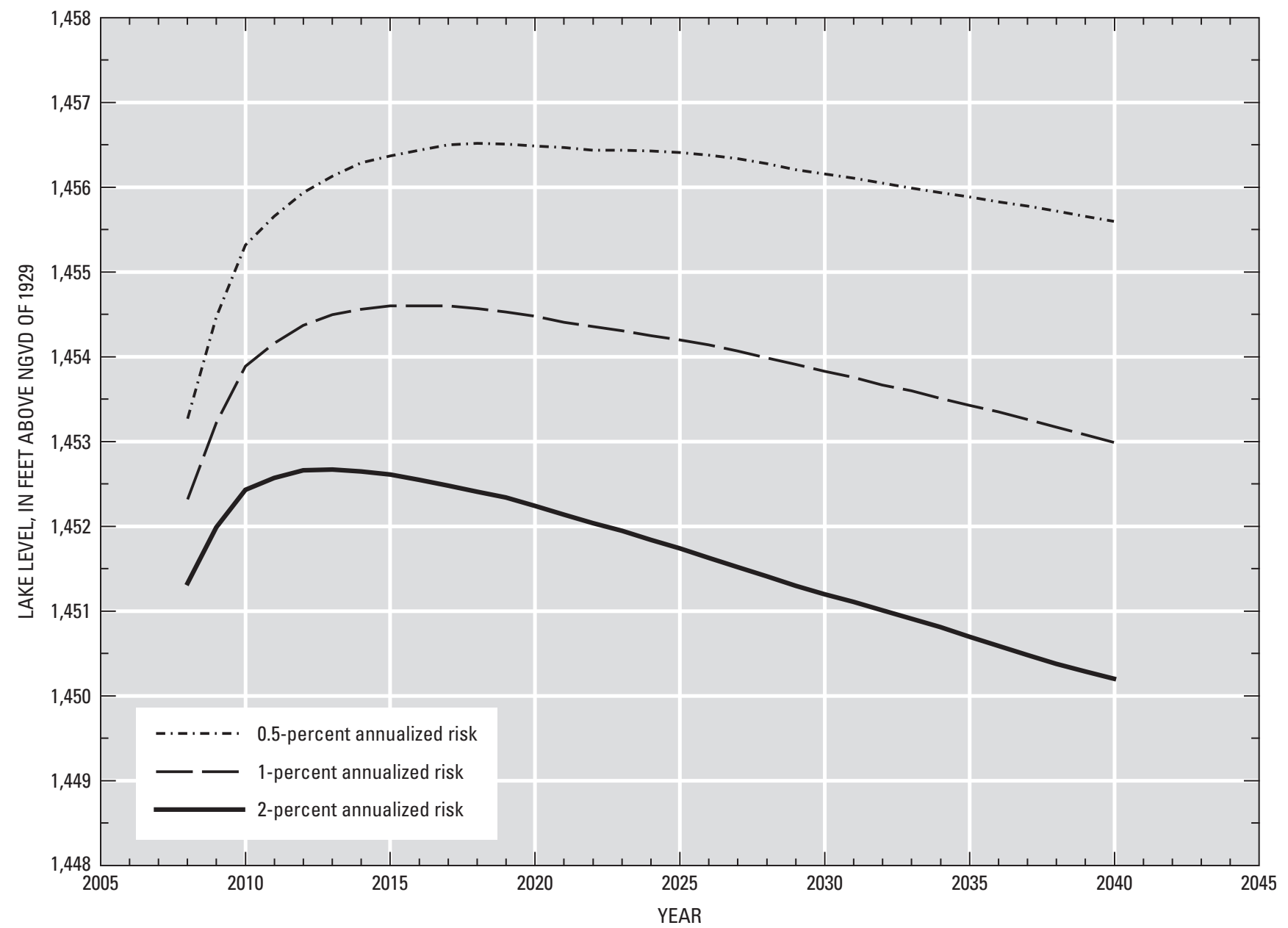

Figure 13. Flood elevations for Devils Lake for 2008-40 for annualized risks of $0.5,1$, and 2 percent, computed by using 10,000 traces from the Devils Lake stochastic simulation model (flood elevations are for calm conditions and open water). 
Table 4. Flood elevations for Devils Lake for 2008-40 for annualized risks of $0.5,1$, and 2 percent.

[Flood elevations are for calm conditions and open water]

\begin{tabular}{|c|c|c|c|}
\hline \multirow{2}{*}{ Year } & \multicolumn{3}{|c|}{ Annualized risk, in percent } \\
\hline & 0.5 & 1 & 2 \\
\hline 2008 & $1,453.3$ & $1,452.3$ & $1,451.3$ \\
\hline 2009 & $1,454.5$ & $1,453.2$ & $1,452.0$ \\
\hline 2010 & $1,455.3$ & $1,453.9$ & $1,452.4$ \\
\hline 2011 & $1,455.7$ & $1,454.2$ & $1,452.6$ \\
\hline 2012 & $1,455.9$ & $1,454.4$ & $1,452.7$ \\
\hline 2013 & $1,456.1$ & $1,454.5$ & $1,452.7$ \\
\hline 2014 & $1,456.3$ & $1,454.6$ & $1,452.6$ \\
\hline 2015 & $1,456.4$ & $1,454.6$ & $1,452.6$ \\
\hline 2016 & $1,456.4$ & $1,454.6$ & $1,452.6$ \\
\hline 2017 & $1,456.5$ & $1,454.6$ & $1,452.5$ \\
\hline 2018 & $1,456.5$ & $1,454.6$ & $1,452.4$ \\
\hline 2019 & $1,456.5$ & $1,454.5$ & $1,452.3$ \\
\hline 2020 & $1,456.5$ & $1,454.5$ & $1,452.2$ \\
\hline 2021 & $1,456.5$ & $1,454.4$ & $1,452.1$ \\
\hline 2022 & $1,456.4$ & $1,454.4$ & $1,452.0$ \\
\hline 2023 & $1,456.4$ & $1,454.3$ & $1,452.0$ \\
\hline 2024 & $1,456.4$ & $1,454.2$ & $1,451.8$ \\
\hline 2025 & $1,456.4$ & $1,454.2$ & $1,451.7$ \\
\hline 2026 & $1,456.4$ & $1,454.1$ & $1,451.6$ \\
\hline 2027 & $1,456.3$ & $1,454.1$ & $1,451.5$ \\
\hline 2028 & $1,456.3$ & $1,454.0$ & $1,451.4$ \\
\hline 2029 & $1,456.2$ & $1,453.9$ & $1,451.3$ \\
\hline 2030 & $1,456.2$ & $1,453.8$ & $1,451.2$ \\
\hline 2031 & $1,456.1$ & $1,453.8$ & $1,451.1$ \\
\hline 2032 & $1,456.0$ & $1,453.7$ & $1,451.0$ \\
\hline 2033 & $1,456.0$ & $1,453.6$ & $1,450.9$ \\
\hline 2034 & $1,455.9$ & $1,453.5$ & $1,450.8$ \\
\hline 2035 & $1,455.9$ & $1,453.4$ & $1,450.7$ \\
\hline 2036 & $1,455.8$ & $1,453.4$ & $1,450.6$ \\
\hline 2037 & $1,455.8$ & $1,453.3$ & $1,450.5$ \\
\hline 2038 & $1,455.7$ & $1,453.2$ & $1,450.4$ \\
\hline 2039 & $1,455.7$ & $1,453.1$ & $1,450.3$ \\
\hline 2040 & $1,455.6$ & $1,453.0$ & $1,450.2$ \\
\hline
\end{tabular}




\section{Summary}

Devils Lake and Stump Lake in northeastern North Dakota receive surface runoff from a 3,810-square-mile drainage basin, and evaporation provides the only major water loss unless the lakes are above their natural spill elevation to the Sheyenne River. From 1992 to 2007, above-normal precipitation and runoff caused Devils Lake and Stump Lake to increase in combined volume by about 2.3 million acre-feet and increase in combined area by about 91,000 acres. The rising water has destroyed hundreds of homes and businesses, inundated thousands of acres of productive farmland, and cost more than \$450 million in flood-mitigation efforts such as raising levees and roads. On September 30, 2007, flow from Devils Lake to Stump Lake had filled Stump Lake and the two lakes consisted of essentially one water body with an elevation of 1,447.1 feet, about 3 feet below the existing base flood elevation (1,450 feet) and about 12 feet below the natural outlet elevation (1,459 feet). The lakes could continue to rise above the natural outlet, causing extensive additional flood damages in the basin and, in the event of an uncontrolled natural spill, downstream in the Red River of the North Basin. This report describes the results of a study conducted by the U.S. Geological Survey, in cooperation with the Federal Emergency Management Agency, to evaluate future flood risk for Devils Lake and provide information for developing updated floodinsurance rate maps and planning flood-mitigation activities such as raising levees or roads.

Unlike riverine floods, which primarily depend on shortterm precipitation or snowmelt events, Devils Lake flooding primarily depends on long-term climatic conditions in the basin. Therefore, understanding long-term climate variability is important for evaluating future flood risk for Devils Lake. In about 1980, a large, abrupt, and highly significant increase in precipitation occurred in the Devils Lake Basin and elsewhere in the Northern Great Plains, and wetter-than-normal conditions have persisted through the present (2007). Although future precipitation is impossible to predict, paleoclimatic data and recent research on climate dynamics indicate that climatic conditions in the Devils Lake Basin in the distant past and the near future may consist of two equilibrium states: a dry state similar to 1950-79 and a wet state similar to 1980-2006. Existence of any intermediate states, or more extreme dry or wet states, is unlikely. The average duration of the wet states was estimated to be 30 years and the average duration of the dry states was estimated to be 120 years. However, the number of years left in the current wet period is highly random and it is not likely the current wet period will end anytime soon-there is about a 72-percent chance it will last at least 10 more years and about a 37-percent chance it will last at least 30 more years.

A stochastic simulation model for Devils Lake developed in a previous study was updated and used to generate 10,000 potential future realizations, or traces, of Devils Lake precipitation, evaporation, inflow, and lake levels given existing conditions on September 30, 2007, and randomly generated future duration of the current wet period. The generated traces were used to compute cumulative flood elevations for 2008-40 by computing the elevations that have a fixed probability of being exceeded sometime between now and a given future year. For example, there is about a 1-percent chance of Devils Lake exceeding 1,459.9 feet ( 0.9 foot above the natural spill elevation), a 5-percent chance of exceeding 1,455.7 feet, and a 10-percent chance of exceeding 1,453.8 feet sometime between 2008 and 2015. Although the risk of much higher lake levels in future years is relatively high, there is also about a 50-percent chance the lake will not exceed 1,450 feet (less than 1 foot above the historical record level of 1,449.2 feet set in 2006) anytime during 2008-40.

Flood elevations used for flood-insurance rate maps generally assume a fixed probability, such as 1 percent, of exceeding the flood elevation in a single year. Unlike riverine floods, in which the flood elevation is the same each year, the flood elevation for Devils Lake depends on which year is specified. For example, there is about a 1-percent chance of Devils Lake exceeding 1,452.3 feet in 2008 and about a 1-percent chance of exceeding 1,456 feet in 2010. Therefore, flood elevations were computed for Devils Lake for which the "annualized" flood risk, defined as the average annual probability of exceeding the flood elevation for a certain future time horizon, was fixed. The Devils Lake flood elevation for an annualized flood risk of 1 percent (analogous to a "100-year" riverine flood) was estimated to be 1,454.6 feet for a 10-year time horizon (2008-17). Therefore, a residence near Devils Lake at elevation 1,454.6 feet has the same chance of being flooded sometime during the next 10 years as a residence at the edge of the 100-year flood plain along a river. The Devils Lake residence would be less likely to flood early in the 10-year period and more likely to flood later in the 10-year period than the residence along the river, but the average risk over the next 10 years would be the same. The flood elevations in this report are for the USGS gage on Creel Bay of Devils Lake and were not adjusted for the effects of wind or ice. The basic flood-elevation maps produced by FEMA for locations around the lake will include adjustments for the effects of wind and ice, and thus the published flood elevations for many locations may be higher than the elevations reported here. 


\section{References Cited}

Bluemle, J.P., 1996, North Dakota Geological Survey newsletter: v. 23 , no. 1, p. $1-2$.

Demaree, G.R., and Nicolis, C., 1990, Onset of Sahelian drought viewed as a fluctuation-induced transition: Quarterly Journal of the Royal Meteorological Society, v. 116, p. 221-238.

Devore, J.L., 1987, Probability and Statistics for Engineering and the Sciences: Brooks/Cole, Monterey, California, 672 p.

Enfield, D.B., and Cid-Serrano, L., 2006, Projecting the risk of future climate shifts: International Journal of Climatology, v. 26, p. $885-895$.

Federal Emergency Management Agency, 2000, Code of Federal Regulations, Title 44, Part 67.

Garbrecht, J.D., and Rossel, F.E., 2002, Decade-scale precipitation increase in the Great Plains at the end of the 20th century: Journal of Hydrologic Engineering, v. 7, Issue 1, p. 64-75.

High Plains Regional Climate Center, 2006, Climate data, accessed June 15, 2007 at http://www.hprcc.unl.edu/

McCabe, G.J, Betancourt, J.L,, and Hidalgo, H.G., 2007, Associations of decadal to multidecadal sea-surface temperature variability with upper Colorado River Flow: Journal of the American Water Resources Association, v. 43, no. 1, p. 183-192.

Murphy, E.C., Fritz, A.K., and Fleming, R.F., 1997, The Jerusalem and Tolna outlets in the Devils Lake Basin, North Dakota: North Dakota Geological Survey Report of Investigation No. 100, 36 p.

North Dakota State Water Commission, 2007, Devils Lake Emergency Outlet Information, accessed June 15, 2007 at http://www.swc.state.nd.us/4dlink9/4dcgi/ GetSubCategoryRecord/ Devils\%20Lake\%20Flooding/ Outlet

Schuh, W.M., and Hove, M.H., 2006, Sources and processes affecting dissolved sulfate concentrations in the Upper Sheyenne River: North Dakota State Water Commission Report, 52 p.
Schwierz, C., Appenzeller, C., Davies, H.C., Liniger, M.A., Muller, W., Stocker, T.F., and Yoshimori, M., 2006, Challenges posed by and approaches to the study of seasonal-todecadal climate variability: Climatic Change, v. 79 , p. 31-63.

Shabbar, A., 2006, The impact of El Niño-Southern Oscillation on the Canadian climate: Advances in Geosciences, v. 6, p. 149-153.

Shapley, M.D., Johnson, W.C., Engstrom, D.R., and Osterkamp, W.R., 2005, Late-Holocene flooding and drought in the Northern Great Plains, USA, reconstructed from tree rings, lake sediments, and ancient shorelines: The Holocene, v. 15, p. 29-41.

U.S. Army Corps of Engineers, 2003, Final Devils Lake, North Dakota Integrated Planning Report and Environmental Impact Statement: St. Paul District, COE, various pagination.

Vance, R.E., Mathewes, R.W., and Clague, J.J, 1992, 7,000-year record of lake-level change on the northern Great Plains: A high-resolution proxy of past climate: Geology, v. 20, p. 879-882.

Vecchia, A.V., 2002, Simulation of a proposed emergency outlet from Devils Lake, North Dakota: U.S. Geological Survey Water-Resources Investigations Report 02-4042, 129 p.

Wang, G., 2004, A conceptual modeling study on biosphereatmosphere interactions and its implications for physically based climate modeling: Journal of Climate, v. 17, p. 2572-2583.

Wiche, G.J., and Pusc, S.W., 1994, Hydrology of the Devils Lake area, North Dakota: North Dakota State Water Commission, Water Resources Investigation 22, 24 p.

Wiche, G.J., and Vecchia, A.V., 1996, Lake-level frequency analysis for Devils Lake, North Dakota: U.S. Geological Survey Water-Supply Paper 2469, 57 p.

Wiche, G.J., Vecchia, A.V., Osborne, L., Wood, C.M., and Fey, J.T., 2000, Climatology, hydrology, and simulation of an emergency outlet, Devils Lake Basin, North Dakota: U.S. Geological Survey Water-Resources Investigations Report 00-4174, 16 p.

Yonetani, T., and Gordon, H.B., 2001, Abrupt changes as indicators of decadal climate variability: Climate Dynamics, v. 17, p. 249-258. 


\section{Appendix}


Estimated Monthly Precipitation, Evaporation, and Inflow for Devils Lake for 2000-2006.

\begin{tabular}{|c|c|c|c|c|c|c|c|c|c|c|c|c|}
\hline \multicolumn{13}{|c|}{ Month } \\
\hline Year & Jan & Feb & Mar & Apr & May & June & July & Aug & Sept & Oct & Nov & Dec \\
\hline \multicolumn{13}{|c|}{ Precipitation, in inches } \\
\hline 2001 & .23 & .78 & .35 & 2.03 & 2.20 & 5.40 & 5.31 & 1.58 & .64 & 2.06 & .21 & .42 \\
\hline 2002 & .23 & .09 & .49 & .70 & 1.03 & 4.27 & 2.33 & 5.78 & 2.55 & .67 & .18 & .69 \\
\hline 2004 & 1.44 & .48 & 4.78 & .43 & 6.04 & 1.12 & 1.97 & 4.02 & 3.38 & 1.25 & .15 & .48 \\
\hline 2005 & .69 & .11 & .53 & .95 & 3.83 & 8.32 & 3.11 & 2.95 & .31 & 1.51 & 1.56 & 1.06 \\
\hline 2006 & .30 & .63 & 1.43 & 1.73 & 1.23 & 2.06 & 1.08 & 3.33 & .94 & 1.26 & .07 & .81 \\
\hline \multicolumn{13}{|c|}{ Evaporation, in inches } \\
\hline 2003 & 0 & 0 & 0 & 1.40 & 3.70 & 5.23 & 5.49 & 6.82 & 5.06 & 3.85 & .68 & 0 \\
\hline 2004 & 0 & 0 & 0 & 1.35 & 3.48 & 5.22 & 5.12 & 4.71 & 4.01 & 2.85 & 2.00 & 0 \\
\hline 2005 & 0 & 0 & 0 & 1.57 & 3.51 & 4.64 & 5.42 & 6.05 & 5.26 & 2.86 & .97 & 0 \\
\hline 2006 & 0 & 0 & 0 & 1.29 & 4.23 & 5.90 & 7.37 & 6.89 & 5.01 & 2.93 & 1.60 & 0 \\
\hline \multicolumn{13}{|c|}{ Inflow, in thousand acre-feet } \\
\hline 2000 & 0 & 0 & 1.8 & 1.9 & 1.0 & 2.0 & 11.1 & 4.6 & 3.8 & 0.5 & 0 & 0 \\
\hline 2001 & 0 & 0 & 0 & 151.6 & 50.2 & 23.4 & 16.2 & 13.9 & 2.2 & .1 & 0 & 0 \\
\hline 2002 & 0 & 0 & 0 & .5 & .9 & 42.4 & 17.2 & 3.3 & 3.4 & .5 & 0 & 0 \\
\hline
\end{tabular}




\section{Climate Transition Model}

The climate transition model was derived by using the annual precipitation data (fig. 6) and the techniques of Demaree and Nicolis (1990). They show that the following stochastic nonlinear differential equation can be used to model long-term climate fluctuations:

$$
\frac{d}{d t} X(\rho t)=-[X(\rho t)]^{3}+\lambda[X(\rho t)]^{2}-\mu[X(\rho t)]+v+\sigma F(t)
$$

where $X\left(t^{*}\right)$ (with $t^{*}=\rho t$ ) is a climatic variable for time $t^{*}$, in decimal years, $F(t)$ is a Gaussian white noise time series with mean zero and variance one, and $\rho, \lambda, \mu, v$, and $\sigma$ are model parameters. They also show that under general conditions on the parameters, $X\left(t^{*}\right)$ has two equilibrium states, $X\left(t^{*}\right) \approx M_{1}+S_{1} Y_{1}\left(t^{*}\right)$ and $X\left(t^{*}\right) \approx M_{2}+S_{2} Y_{2}\left(t^{*}\right)$, where $M_{i}$ and $S_{i}$ are the mean and standard deviation of the $i$ th state and $Y_{i}\left(t^{*}\right)$ is a stochastic process with a mean of zero and a standard deviation of one (the properties of $Y_{i}\left(t^{*}\right)$ are not important for purposes of this report). They express the parameters of the model (A1) in terms of the means and standard deviations of the two equilibrium states. In particular,

$$
\lambda=M_{1}+M_{2}+B ; \mu=B\left(M_{1}+M_{2}\right)+M_{1} M_{2} ; \text { and } v=B M_{1} M_{2} \text {, }
$$

where

$$
B=\left(M_{1} S_{1}^{2}+M_{2} S_{2}^{2}\right) /\left(S_{1}^{2}+S_{2}^{2}\right),
$$

and

$$
\sigma^{2}=2 S_{2}^{2}\left[M_{2}^{2}-M_{1} M_{2}-B\left(M_{2}-M_{1}\right)\right] .
$$

The remaining parameter $(\rho)$ needs to be estimated through simulation analysis as described later in this section.

The climatic time series selected for the climate transition model $(X)$ was derived from the annual precipitation time series for Devils Lake (fig. 6),

$$
X\left(t^{*}\right)=P_{5}\left(t^{*}\right)-20.3
$$

where

$$
P_{5}\left(t^{*}\right) \quad \text { is average annual precipitation for Devils Lake for the } 5 \text { years up to and including time } t^{*} \text {. }
$$

The 5-year moving average was used to smooth out some of the noise in the data that was not expected to represent regional climate variability. The constant (20.3) is the average annual precipitation for 1950-2006 and was subtracted strictly for numerical purposes. Values obtained by using 1950-79 to represent the first state and 1980-2006 to represent the second state were $M_{1}=-1.9, M_{2}=2.1, S_{1}=0.30$, and $S_{2}=0.58$. Using these values in the previous formulas (A1-A4) gives

$$
B=1.2 ; \lambda=1.32 ; \mu=-4.08 ; v=-5.14 ; \text { and } \sigma^{2}=2.41 \text {. }
$$

The remaining parameter $(\rho)$ determines the rate at which $X\left(t^{*}\right)$ cycles between the two equilibrium states. It was estimated by substituting values into model A1 (with the other parameters fixed), numerically simulating a long (50,000-year) precipitation time series, and selecting the value such that the average recurrence interval of the wet periods was 150 years. A recurrence interval of 150 years was selected to agree with Shapley and others (2005), who estimated an average recurrence interval of 140-160 years for the wet periods on the basis of tree-ring and lake-sediment data. The average recurrence intervals for selected values of $\rho$ are given in the following table.

Table A1. Recurrence intervals and average durations of wet and dry periods.

\begin{tabular}{cccc}
\hline Value for $\rho$ & $\begin{array}{c}\text { Average recurrence interval for } \\
\text { wet periods, in years }\end{array}$ & $\begin{array}{c}\text { Average duration of } \\
\text { wet periods, in years }\end{array}$ & $\begin{array}{c}\text { Average duration of } \\
\text { dry periods, in years }\end{array}$ \\
\hline 0.35 & 169 & 32 & 137 \\
.40 & 146 & 29 & 117 \\
.45 & 102 & 24 & 78 \\
\hline
\end{tabular}


On the basis of table A1, $\rho=0.40$ was selected, which yields an average recurrence interval of 146 years for the wet periods, an average duration of 29 years for the wet periods, and an average duration of 117 years for the dry periods. Part of the 50,000-year generated time series for the selected value of $\rho$ is shown in figure 9. For comparison, to demonstrate the sensitivity to the value of $\rho$, a segment of the generated data with $\rho=0.45$ is shown in figure A1.

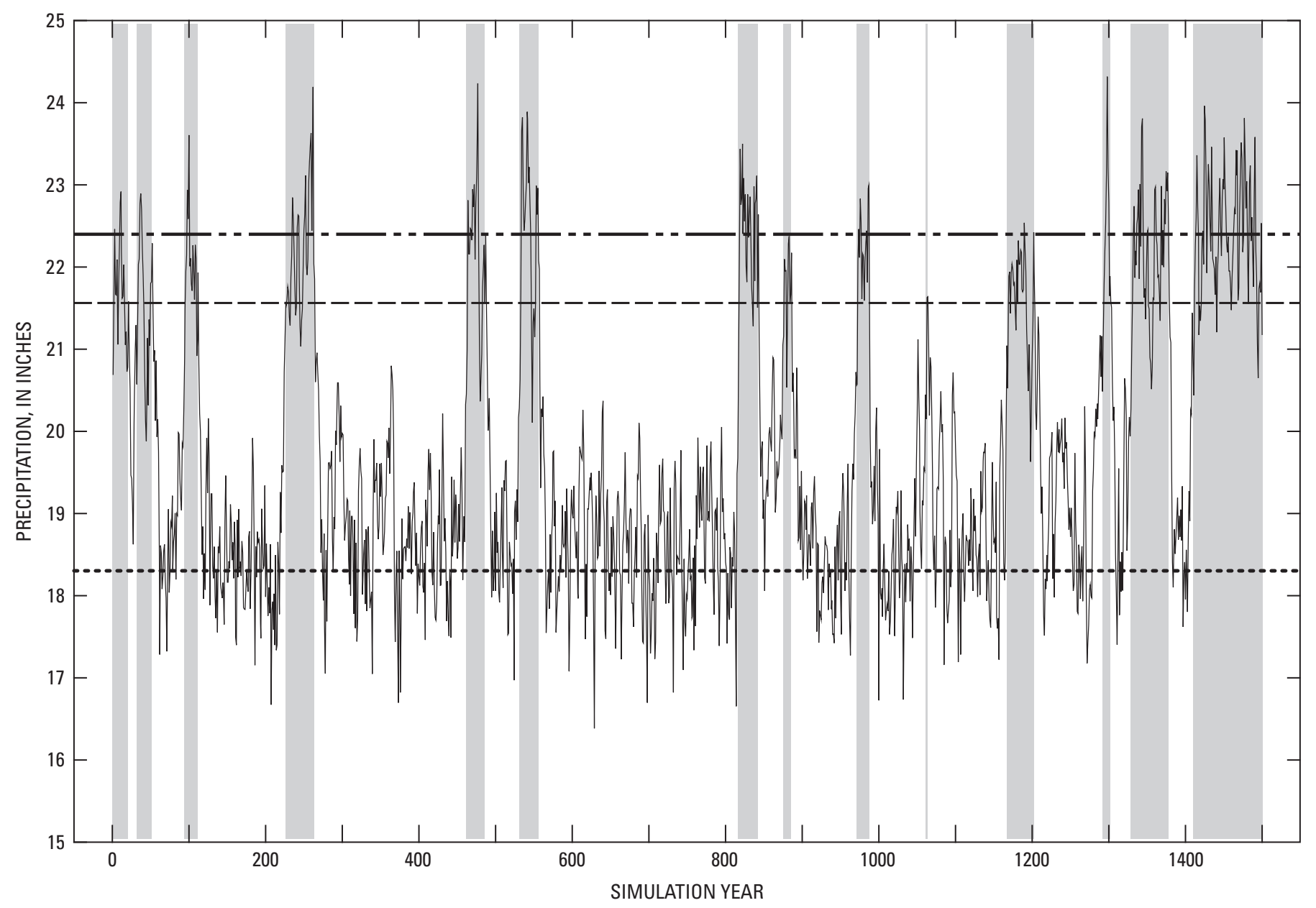

EXPLANATION

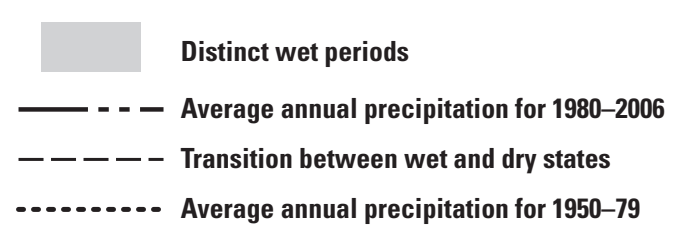

Figure A1. Five-year moving average of annual precipitation for 1,500 years generated from the climate transition model with 24-year average duration of the wet periods and 78-year average duration of the dry periods.

The middle line in figure A1 (and fig. 9) is the transition point between the wet and dry periods and is given by B+20.3=21.5 inches. A wet period was assumed to start when the time series first crossed the transition line, and the subsequent dry period was assumed to start when the time series was below the transition line for 10 years in a row. 


\section{Time Series Model for Generating Precipitation, Evaporation, and Inflow}

Minor modifications to the model developed and verified by Vecchia (2002, p. 74-82) were needed to generate input data for this study. The model depends on whether the climate state is wet or dry. The same period (1950-79) used in the previous study to represent the dry period was used here, so no modifications were needed. However, 1980-2006 was used in this study to represent the wet period whereas 1980-99 was used previously. The only other modification was with regard to the climate transition model, which used average durations of 30 years and 120 years for the wet and dry periods, respectively, for this study compared with 20 years and 120 years in the previous study.

Some statistical properties of the generated annual precipitation, evaporation, and inflow data for the representative climate periods (obtained by aggregating the monthly data) are given in table A2. For precipitation, use of the 1980-2006 climate period resulted in small decreases of 0.1 to 0.2 inch in the mean and all of the percentiles compared to the 1980-99 climate period. For evaporation, the mean and median of the data from use of the 1980-2006 and 1980-99 climate periods were the same. However, the spread of the data was slightly smaller using the 1980-2006 period: the 1st and 99th percentiles were 24.1 and 38.2 inches, respectively, for 1980-2006 compared to 23.9 and 38.8 inches for 1980-99. For inflows, the mean was somewhat smaller for 1980-2006 compared to 1980-99 (about 108 compared to about 116 thousand acre-feet), primarily owing to the small decrease in precipitation. The largest differences occurred for high inflow percentiles, in which the percentiles for 1980-2006 were considerably smaller than those for 1980-99. The 99th percentile for 1980-2006 was about 860 thousand acre-feet, compared to about 932 thousand acre-feet for 1980-99. The decrease in the upper tail of the inflow distribution was due to a combination of the increase in the lower tail of the evaporation distribution and the decrease in the upper tail of the precipitation distribution. A somewhat smaller chance of having an extremely cool, wet summer, such as occurred in 1993, resulted from the use of 1980-2006 as the representative climate period.

Table A2. Statistical properties of generated annual precipitation, evaporation, and inflow data for Devils Lake for representative climate periods 1950-79, 1980-99, and 1980-2006.

\begin{tabular}{|c|c|c|c|c|c|c|}
\hline \multirow{2}{*}{ Climatic period } & \multirow{2}{*}{ Mean } & \multicolumn{5}{|c|}{ Percentile } \\
\hline & & 1 & 10 & 50 & 90 & 99 \\
\hline \multicolumn{7}{|c|}{ Precipitation, in inches } \\
\hline 1950-1979 & 18.4 & 10.0 & 13.3 & 18.2 & 24.6 & 30.9 \\
\hline 1980-1999 & 22.5 & 13.1 & 16.8 & 22.1 & 28.9 & 35.7 \\
\hline 1980-2006 & 22.4 & 13.0 & 16.5 & 22.0 & 28.7 & 35.5 \\
\hline \multicolumn{7}{|c|}{ Evaporation, in inches } \\
\hline 1950-1979 & 28.5 & 23.4 & 25.6 & 28.5 & 31.4 & 34.2 \\
\hline 1980-1999 & 30.9 & 23.9 & 26.9 & 30.8 & 35.0 & 38.8 \\
\hline 1980-2006 & 30.9 & 24.1 & 27.0 & 30.8 & 34.8 & 38.2 \\
\hline \multicolumn{7}{|c|}{ Inflow, in thousand acre-feet } \\
\hline 1950-1979 & 24.9 & 0.0 & 0.2 & 4.5 & 65.4 & 273.3 \\
\hline 1980-1999 & 115.7 & .1 & 1.9 & 44.5 & 310.5 & 931.7 \\
\hline 1980-2006 & 108.2 & .1 & 1.5 & 39.2 & 294.2 & 859.5 \\
\hline
\end{tabular}




\section{Assumptions Used for Emergency Outlet}

Besides the differences between the simulations from Vecchia (2002) and this report that were described in the previous section, the only other difference was with regard to the assumptions for the Devils Lake outlet. In the previous report, the outlet simulations were for a proposed outlet from Devils Lake that was being considered by the COE. That outlet has not been constructed at this time (2007). However, the State of North Dakota did construct an emergency outlet from West Bay of Devils Lake (fig. 2) that became operational in 2005 (North Dakota State Water Commission, Devils Lake online information, accessed September 1, 2007). The outlet operational details effective on October 1, 2007, were used for all simulations described in this report (table A3).

Table A3. Assumptions regarding North Dakota Devils Lake Emergency Outlet.

\begin{abstract}
Window of operation:
Pump capacity:

Downstream channel capacity:

Downstream sulfate constraint:

April 1 through November 30

100 cubic feet per second

600 cubic feet per second (combined outlet and ambient Sheyenne River flow cannot exceed 600 cubic feet per second)

If ambient Sheyenne River concentration is less than 260 milligrams per liter, combined outlet and ambient Sheyenne River flow cannot exceed 300 milligrams per liter. If ambient concentration is between 260 and 390 milligrams per liter, combined outlet and ambient flow cannot exceed 1.15 times the ambient concentration. If ambient concentration is greater than 390 milligrams per liter, combined outlet and ambient flow cannot exceed 450 milligrams per liter.
\end{abstract}

Starting sulfate concentrations:

Ambient Sheyenne River sulfate:

Concentrations for Devils Lake bays on September 30, 2007, were computed by using concentra(620 mg/L); Main Bay (640 mg/L); East Bay (880 mg/L); East Devils Lake (1,140 mg/L).

Generated concentrations 2.2 times the concentrations generated using the algorithm from Vecchia tions measured by North Dakota Department of Health as close to that date as possible (Mike Ell, North Dakota Department of Health, written commun., 2007): Pelican Lake (490 mg/L); West Bay (2002)

Recent measured sulfate concentrations from the Sheyenne River near the outlet insertion were much higher than assumed in previous simulations (Schuh and Hove, 2006). Therefore, the concentrations generated by using the algorithm from Vecchia (2002) were multiplied by 2.2 , which was the average ratio of the measured concentrations at the insertion point for 2007 to those generated by using the previous algorithm.

The amount of water discharged from the outlet was highly variable from trace to trace in the climate simulations. As expected, the traces for which the lake levels increased substantially during the next few years (beginning in 2008) generally were the traces with the most outlet discharges. Ten percent $(1,000)$ of the traces had at least 25,800 acre-feet of total outlet discharge during 2008-10 and at least 72,200 acre-feet of total discharge during 2008-17. One percent (100) of the traces had at least 45,900 acre-feet of total outlet discharge during 2008-10 and at least 143,000 acre-feet of discharge during 2008-17. Although analyzing the effect of the outlet on flood elevations was not part of the scope of this study, the traces were run both with and without the outlet. The cumulative flood elevations without the outlet generally were 0.1 to 0.3 foot higher than the values shown in table 3 . The largest differences (about 0.3 foot) were for the 5 - and 10 -percent cumulative exceedance probabilities, intermediate differences (about 0.2 foot) for the 1- and 20-percent cumulative exceedance probabilities, and the smallest differences (about 0.1 foot) for the 50 -percent cumulative exceedance probability. 
Publishing support provided by:

Helena Publishing Service Center

For more information concerning this publication, contact: Director, USGS North Dakota Water Science Center 821 E. Interstate Ave.

Bismarck, ND 58503

(406) 457-5900

Or visit the North Dakota Water Science Center Web site at: http://nd.water.usgs.gov 
